\title{
The Effect of Visual Feedback on the Voice Control Ability of Pre-lingual Deafened Young Adults with Cochlear Implants
}

\author{
Ji Eun Kang, Youngmee Lee, Hyun Sub Sim \\ Department of Communication Disorder, Ewha Womans University, Seoul, Korea
}

Correspondence: Hyun Sub Sim, PhD Department of Communication Disorders, Ewha Womans University, 52 Ewhayeodae-gil, Seodaemun-gu, Seoul 03760, Korea

Tel: $+82-2-3277-2120$

Fax: $+82-2-3277-2122$

E-mail: simhs@ewha.ac.kr

Received: April 5, 2021

Revised: May 11, 2021

Accepted: May 21, 2021
Objectives: The purpose of this study is to investigate whether there is a difference in the voice control ability between young adults with cochlear implants $(\mathrm{Cls})$ and a normal hearing $(\mathrm{NH})$ group. This study examined the correlation between Cl-related characteristics, performance, and acoustic measurements (i.e., voice dynamic area, voice range profile slope). Methods: Participants were 12 young adults (8 females and 4 males) who had Cls before 7 years of age, and $12 \mathrm{NH}$ young adults who matched their sex and age. A voice range profile (VRP) program was used to evaluate voice control ability according to the presence or absence of visual feedback. Results: The voice dynamic area (VDA) of the $\mathrm{NH}$ group was significantly larger than that of the $\mathrm{Cl}$ group, and the VDA was significantly greater when the visual-auditory feedback was presented rather than relying solely on hearing. There was no significant difference between the groups in the VRP slope, but the slope was significantly smaller when the visual-auditory feedback was provided than when only the auditory feedback was provided. There was a negative correlation between the consonant accuracy and the VRP slope in the $\mathrm{Cl}$ group. Conclusion: Congenitally deafened young adults didn't achieve normal voice control abilities in comparison with $\mathrm{NH}$. However, $\mathrm{Cls}$ were able to use the visual information in order to better control their voice. Additionally, the VDA is appropriate as a variable to measure the voice control ability of Cls, but the VDA and the VRP slope are complementary and need to be considered together when analyzing the results.

Keywords: Voice control, Voice range profile, Voice dynamic area, VRP slope, Cochlear implants, Visual feedback
화자의 음성 특성을 결정하는 구조는 후두, 성대, 폐 등의 발성 기관이다. 일반적으로 변성기에 후두 위치가 하강하며 성대 전체 길이가 증가하고 성대의 두께는 두꺼워져 음성 변화가 나타난다 (Ko et al., 2013). 보통 11세에서 16세 사이에 변성기를 경험하며 (Boone, McFarlane, Von Berg, \& Zraick, 2014; Kim, 2008; Pedersen, 1993), 여성보다 남성의 음성 변화가 더 뚜렷하게 나타난다(Wang et al., 1996). 변성기가 지난 16-18세 청소년기의 남학생과 여학생의 음성은 초기 성인 수준에 도달해 성인과 비슷한 발성 특성을 보이 게 된다. 그러나 청각장애 청년은 제한된 청각적 피드백(auditory feedback)으로 인해 음도, 강도, 강세, 공명, 음질 등 초분절적인 요
소에서 문제가 발생하여, 정상 청력 청년의 발성 패턴과 다른 특징 을 보이게 된다(Bae, Park, Kwon, Lee, \& Koh, 2014; Boone et al., 2014). 청각장애인은 높은 주파수 및 강도를 보일 뿐 아니라, 발화 중 음도와 강도 변화가 더 크게 나타난다. 즉, 자신의 음성을 정상 청력 청년처럼 유연하고 정교하게 조절하지 못한다(Boone et al., 2014; Elizabeth, Justin, Abbigail, EmilyAnn, \& Bailey, 2018; Lee, 2012; Yoon, 2006).

인공와우이식(cochlear implantation)은 말소리 지각, 말 명료도 뿐만 아니라 청각장애인의 음성에도 긍정적인 영향을 미치는 것으 로 알려져 있다(Hamzavi, Deutsch, Baumgartner, Bigenzahn, \& 
Gstoettner, 2000; Langeries, Bosman, \& van Olphen, 1998). 인공 와우이식 시기는 수술 후의 말 산출 능력에 가장 큰 영향을 주는 것으로 알려져 있다(Yoon, 2003). 인공와우이식으로 교정 청력이 상승하면서 소리에 대한 범주화 과정을 거치고 정상적인 음도와 강 도를 산출하는 데 도움이 되지만, 인공와우 기기의 제한점으로 인 해서 음의 높낮이 관련 정보의 양과 질에는 한계가 있다(Jung, 2010). 즉, 인공와우는 제한된 수의 전극을 통하여 스펙트럼-시간적 미세 구조(spectro-temporal fine structure) 정보를 청신경까지 전달하 는 데 한계가 있어 음도에 대한 정확한 변별이 어렵다(Kong, Mullangi, Marozeau, \& Epstein, 2011). 게다가 변성기를 지나초기 성인 의 음성 수준을 갖춘 청년들은 음성조절에 관여하는 근육과 신경 계의 발달이 이미 완성되어 자신의 부적절한 음성에 이미 적응한 상태이므로(Euh \& Yoon, 2005; Hocevar-Boltezar et al., 2006), 아 동에 비해 음도와 강도를 포함한 음향적 특성을 개선하기에 더 큰 어려움이 따른다. 즉, 인공와우이식 청년은 제한된 청각적 피드백 이 불필요한 성대 긴장을 유발하고, 성문하압과 후두근의 미숙한 조절 등 발성 기관의 불안정한 기능을 야기하여 농인의 음성(deaf voice)이라고 불리는 독특한 특징을 보이게 된다(Yoon, 2006). 따라 서 수년 동안 언어청능재활을 받아 정상 청력 청년과 의사소통이 가능하고 원만한 사회생활을 하는 인공와우이식 청년이 마지막까 지 극복하기 어려운 것이 음성조절이다. 최근 인공와우를 이식한 아동 및 성인의 음성에 대한 관심이 높아지면서 음성 특성과 관련 된 연구들이 보고되어 왔으나(Choi \& Park, 2010; Kim \& Ko, 2007; Kim \& Yoon, 2017), 인공와우이식 청년의 음성조절능력에 대한 연 구는 제한적이다.

음성조절능력(voice control ability)은 다양한 청자, 상황, 대화 맥락 등에 따라 자신의 음성을 역동적으로 조절하는 능력이다 (Nadine, Mike, Sophi, \& Carolyn, 2019). 개인의 음성조절능력은 청력 범위와 밀접한 관계가 있다. 정상 청력 청년은 정상적인 청각 적 피드백을 통해 발화 중 음도 및 강도 수준을 조절하여 한 낱말에 서도 다양한 의미를 표현할 수 있다. 예를 들어, '자' 라는 한 낱말은 명령, 질문, 청유 등 다양한 의미를 내포한다. 직장 면접, 이성과의 소개팅, 연설 상황 등과 같은 일상생활에서 상황에 맞는 음성조절 능력은 매우 유용하며, 자기표현을 위한 역동적인 사회적 수단이 다. 게다가 음성조절능력은 의사소통 상황에서의 말 명료도와 관 련이 높아 음성 개선만으로 말 명료도 향상에 도움이 되기 때문에 매우 중요하다(Massen \& Povel, 1985; Yorkston \& Beukelman, 1981; Youdelman, MacEachron, \& McGarr, 1989). 말 명료도는 조 음능력과 높은 상관관계를 가지며, 청각장애인의 높은 자음정확도 는 말 명료도에 긍정적인 영향을 미친다(Yoon, Lee, \& Sim, 2001).
즉, 음성조절능력과 말 명료도 간 관련성과 말 명료도와 자음정확 도 간 관련성을 바탕으로 화자가 자신의 음성을 유연하게 조절하 는 능력과 조음능력 사이의 연관성을 예측할 수 있다. 인공와우이 식 청년은 음성조절의 어려움으로 다양한 억양을 산출하기 어려우 며, 강조하거나 낮추어 말해야 하는 부분을 조절하기 어렵기 때문 에 자칫 단조로운 음성으로 들릴 수 있으며, 정상 청력 청년에 비해 감정을 예민하게 지각하고 표현하는 데 있어서 제한적이다(Wang, Trehub, Volkova, \& van Lieshout, 2013). 인공와우이식 청년의 음 성조절능력의 어려움은 청자가 발화 의미를 오해하거나 이해하지 못하게 하여 의사소통에서 부정적인 경험을 겪게 하며, 직업 선택, 삶의 만족도 등과 같은 인생 전반에 중대한 영향을 미치게 될 것이 다. 즉, 음성조절능력은 사회성 향상과 일상생활에서 타인과의 구 어 의사소통을 위해 반드시 필요하지만, 이에 대한 연구가 미비하 여 더 많은 연구가 이루어져야 한다.

인공와우이식 청년의 비정상적인 음성 변화는 기본주파수(Fundamental Frequency, F0), 강도(intensity), 주파수변동률(jitter), 진 폭변동률(shimmer), 소음 대 배음 비율(NHR), 스펙트럼 기울기 (spectral tilt) 등을 통해 측정할 수 있다. 이처럼 다양한 음향학적 변수들을 통해 인공와우이식 청년의 음성을 분석하였으나, 화자의 발성능력(vocal capability)을 대표하기는 어렵다. 음성범위프로파 일(Voice Range Profile, VRP)은 F0와 각 주파수별 음압수준(Speech Press Level, SPL) 간의 상관관계를 이차원의 히스토그램 도표로 나타낸 것으로(Boone et al., 2014), 최저 및 최대 주파수, 주파수 범 위 등을 산출한다. $\mathrm{VRP}$ 는 진성구에서 가성구까지 다양한 주파수 범위와 강도 범위가 화면상에 기록되어 개인의 생리적 한계가 비스 듬한 타원 형태로 형상화되고(Pabon, 1991), 음성의 역동성, 생리적 음성 한계나 후두적응능력 등을 포함한 화자의 최대발성역치를 평 가할 수 있다(Airainer \& Klingholz, 1991; Bae et al., 2014; Boone et al., 2014; Ferrand, 2012). 또한, 대화상황, 연설 상황, 노래 부르기 등 일상생활에서 화자의 음성 수행력(vocal performance)에 대한 기 능적인 분석을 가능하게 한다. $\mathrm{VRP}$ 를 통해 음도와 강도를 동시에 조절하며 얼마나 역동적인 음성을 산출할 수 있는지 평가하고, 치 료 전과 후의 음성개선 정도를 객관적으로 확인할 수 있으며, 다양 한 장애 집단 간 음성조절능력을 비교할 수 있다. VRP를 사용하여 음도와 강도 각각의 변수에 대한 측정치는 여러 선행연구를 통해 분석되어 왔다(Bae et al., 2014; Choi et al., 2009; Jung, Choi, \& Choi, 2019). 그러나 음도와 강도를 동시에 조절하는 화자의 역동적 인 발성능력을 분석한 연구는 미비하다. 국외에서 VRP의 면적을 통해 음성의 역동성을 측정하였으나(Caffier et al., 2018; Estella et al., 2007), 표준화된 프로토콜이 없어 연구자마다 측정 방법의 차 
이가 있고 최고주파수처럼 수치값만 산출되므로 시각적인 질적 분 석은 어렵다. 따라서 특정 주파수 범위에서 음성 강도를 얼마나 역 동적으로 조절할 수 있는지 평가하는 VRP에서 음성조절능력을 시각적으로 한눈에 파악할 수 있는 새로운 파라미터가 필요하다. 즉, 화자의 음성조절능력을 신뢰롭고 객관적으로 평가할 수 있는 새로운 파라미터를 통해 다양한 집단을 대상으로 음성의 역동성 을 밝혀낼 필요가 있다. 본 연구에서는 MATLAB을 통해 VRP에서 화자가 발성한 픽셀 개수인 ‘음성역동면적'과 ‘VRP 기울기’라는 새 로운 측정치를 도입하여 인공와우이식 청년의 음성조절능력을 평 가하고자 하였다. 음도조절은 성대의 적절한 긴장이 요구되며, 강 도는 성문하압과 성대 사이로 기류가 빠져나갈 때의 압력에 따라 다양하게 변화하며 조절할 수 있다(Boone et al., 2014; Titze, 1994). 음도와 강도를 조절하는 과정에서 VRP에 나타나는 상곡선의 기울 기와 하곡선의 기울기가 비스듬한 타원형을 이루며 음성역동면적 을 형상화하고 음성산출 능력(vocal capacity)의 지표가 된다(Caffier et al., 2018; Estella et al., 2007; Louis et al., 1998; Nora \& Hugo, 2010; Arend, Harm, \& Donald, 1995). 이때 VRP의 기울기는 제한 된 음도 범위에서 얼마나 다양한 강도로 발성하였는가를 나타내는 변수로서 성문하압의 조절과 밀접한 관련이 있다(Åkerlund \& Grmming, 1994; Awan, 1993; Buekers, 1995; Gramming, Sundberg, Ternstrom, Leandersson, \& Perkins, 1988; Nora \& Hugo, 2010). 인공와우이식 청년은 발성과 관련된 근육의 과도한 긴장으 로 음성 산출을 위해 사용하는 기류를 효율적으로 조절하기 어려 워 갑작스러운 강도 증감을 보일 수 있기 때문에(Pyo, 2007; Spector, Subtelny, Whitehead, \& Wirz, 1979) VRP에서 정상 청력 청년과 다른 양상을 보일 것으로 예상된다.

인공와우이식 청년은 음성 산출 시에 제한된 청각적 피드백을 보상하기 위하여 시각적 피드백을 활용할 수 있다. 시각적 피드백 을 이용한 음도 치료는 인공와우이식 성인의 기본주파수 조절에 유용한 것으로 알려져 있다(Boone, 1966; Leder, Spitzer, \& Kirchner, 1987). Kim (2016)은 시각적 단서를 활용한 음정 모방 중심의 가창 프로그램 효과를 보여주었으며, 인공와우이식 아동의 음고 산출 및 가창 수행력은 훈련을 통해 충분히 향상될 수 있음을 밝혔 다. 따라서 인공와우를 이식한 아동 및 성인에게 시각적 피드백의 활용은 소리에 대한 개념 이해를 돕기 위한 장치로서 매우 효과적 일 수 있다(Gfeller, Driscoll, Kenworthy, \& Van, 2011). 그러나 시각 적 피드백은 청각장애 아동의 조음정확도 및 말 명료도 향상과 관 련되어 주로 연구되었으며(Kuk, 1994; Pratt, Heintzelman, \& Deming, 1993; Ryalls, Michallet, \& Le Dorze, 1994; Seo, 1998), 음성을 조절하기 위해 시각적 피드백을 활용한 연구는 아직 부족하다. Euh
와 Yoon (2005)은 시각적 피드백을 사용하여 보청기를 착용한 성 인의 음도를 중재하였으나, 강도와 음도 측면을 모두 다루지 않았으 며 음도의 임계치를 정하여 그 범위 내에서 안정적으로 발성하는 것을 목표로 하였다. 본 연구에서는 실시간으로 자신의 음도와 강 도를 이전에 산출한 음과 비교하여 점진적으로 증가시키고 감소시 키는 과정을 애플리케이션(DevExtras, voice tools)으로 제시하여 시각적 피드백을 제공하고자 하였다. 시각적 피드백은 자신의 음성 조절이 능숙하지 않은 인공와우이식 청년의 발성 특성을 개선시켜 정상 청력 청년과 비슷한 수준으로 역동적인 음성 산출을 유도할 수 있을 것이다. 따라서, 본 연구에서는 인공와우이식 청년과 정상 청력 청년을 대상으로 VRP를 사용하여 시각적 피드백 유무에 따 라 각 집단의 음성조절능력(음성역동면적, VRP 기울기)에 어떠한 차이가 있는지 살펴보고자 하였다. 이를 통해서, 집단 간 비교를 통 하여 인공와우이식 청년의 음성 특성을 파악하고 쉽게 이해할 수 있으며, 음성조절에 대한 시각적 피드백의 효과를 통하여 인공와 우이식 청년의 음성 및 구어 평가와 언어청능재활에 유용한 정보 를 제공하고자 한다.

\section{연구방법}

\section{연구대상}

본 연구에서는 만 16-25세의 인공와우를 이식한 청년 12 명(여성 8 명, 남성 4 명)과 성별 및 연령을 일치시킨 정상 청력 청년 12 명을 연 구 대상자로 선정하였다. 두 집단은 서울, 경기, 대구 지역에 거주하 였으며, 구체적인 대상자 선정 조건은 다음과 같다.

본 연구에 참여한 실험집단은 (1) 언어습득 이전(pre-lingual)에 농이며, (2) 만 7세 이전에 적어도 한 쪽 귀에 인공와우를 이식하였 으며, (3) 2년 이상 언어청능재활을 받은 경험이 있으며, (4) 자기 보 고에 의하여 비흡연자이며, (5) 청각 이외의 구조적 및 기능적 장애 를 동반하지 않으며, (6) 음성 관련 문제(호흡기, 인 · 후두, 기관지 등 의 질환)가 없고, (7) 치료사의 보고에 의하여 구어 의사소통이 가 능한 자를 대상으로 하였다. 생후 약 5년 동안은 청각적 뇌 가소성 (auditory plasticity)과 함께 언어 및 말소리 습득이 활발히 일어나 는 시기이므로 만 5세 이내에 인공와우이식을 받는 것이 의사소통 발달에 적절한 것으로 보고되었다(Archbold et al., 2008; Manrique et al., 1999; O’Donoghue, Nikolopoulos, Archbold, \& Tait, 1998). 그러나 2000년대 초 국내에 도입된 신생아 청각선별검사는 시행된 지 20년이 채 되지 않아 자신의 청력 문제를 지각하지 못하고 유소 아기를 보낸 인공와우이식 청년들이 많다. 또한, 난청의 조기 진단 의 중요성이 강조되지 못했던 과거에는 인공와우이식이 보편화되 
지 않았고, 비싼 수술비용, 부정적인 인식 등으로 인해 인공와우이 식 시기가 늦어지기도 하였다. 따라서 본 연구에서는 인공와우이식 연령을 7세로 다소 넓게 한정하여 만 7세 이전에 청력손실을 경험 한 청년들을 연구대상으로 하였다.

본 연구의 통제집단은 실험집단과 성별 및 연령을 일치시킨 정상 청력 청년으로, (1) 자기 보고에 의하여 비흡연자이며, (2) 음악과 관 련된 전문 훈련(보컬 트레이닝, 성악 등)을 받은 적이 없고, (3) 음성 관련 문제(호흡기, 인 · 후두, 기관지 등의 질환)가 없으며, (4) 휴대용 청력검사기(Interacoustics, Pediatric Audiometer 5)의 500, 1,000, $2,000,4,000 \mathrm{~Hz}$ 에서 청력 역치가 $20 \mathrm{~dB} \mathrm{HL}$ 이하이며, (5) 말 · 언어, 학습과 관련된 문제가 없는 자로 선정하였다.

모든 실험집단은 만 7세 이전에 인공와우를 이식하여 술후 청력 역치가 $40 \mathrm{~dB}$ 이상이며, 언어습득 전에 농이 되었지만 청각장애 발 병 시점과 원인은 상이하였다. 대상자 7명은 선천성 농인으로 출생 시 발생한 청력손실로 인해 정상적인 듣기 경험이 없었으나(ASHA, 2020), 나머지 5명은 출생 후 교통사고, 폐렴, 원인불명 등의 후천적 요인으로 청각장애가 발병하여 청력손실 전 정상적인 듣기 경험이 있었다. 즉, 후천성 농인은 언어습득기인 만 36-72개월 사이에 청력 손실이 발생한 농(peri-lingually deaf)이었다. 또한, 대상자 6명은 일측 인공와우 착용 청년이었으나, 다른 6명은 양측 착용한 순차적 인공와우이식 청년이었다. 대상자의 청력 정보는 Appendix 1에 제 시하였다.

두 집단 간 연령, 교육년수, 한국판 간이정신상태 검사(K-MMSE, Kang, 2006) 점수 차이가 통계적으로 유의한지 알아보기 위하여 각각 독립표본 $t$-검정(two-independent sample $t$-test)을 실시하였 다. 그 결과, 두 집단 간 생활연령, 교육년수, K-MMSE 점수 차이가 통계적으로 유의하지 않았다. 두 집단의 독립표본 $t$-검정 결과는 Table 1에 제시하였다.

\section{연구도구}

본 연구에서는 실험집단과 통제집단의 음성조절능력을 측정하 기 위하여 음향학적 평가도구인 Computerized Speech Lab (CSL;

Table 1. Participants' characteristics

\begin{tabular}{lcc}
\hline Characteristic & $\mathrm{Cl}(\mathrm{N}=12)$ & $\mathrm{NH}(\mathrm{N}=12)$ \\
\hline Age $(\mathrm{yr})$ & $20.00 \pm 2.174(16-25)$ & $20.83 \pm 3.186(16-25)$ \\
Education $(\mathrm{yr})$ & $12.00 \pm 1.379(10-16)$ & $12.25 \pm 1.865(10-16)$ \\
K-MMSE $(\text { score })^{\mathrm{a}}$ & $28.58 \pm 1.379(25-30)$ & $29.33 \pm 1.073(27-30)$
\end{tabular}

Values are presented as mean $\pm \mathrm{SD}$ (range).

$\mathrm{Cl}=$ young adults with cochlear implants; $\mathrm{NH}=$ young adults with normal hearing. aKorean-Mini Mental State Examination, K-MMSE (Kang, 2006).
Model 4150B, Kay Pentax)의 음성범위프로파일(VRP)을 이용하 여 최저 및 최고주파수, 주파수 범위, 최소 및 최대강도, 강도 범위 를 측정하였다. 또한, 음성조절능력과 관련성이 높은 변수를 알아 보기 위해 실험집단을 대상으로 단음절 말지각검사(Lee, Shin, $\mathrm{Kim}, \& \mathrm{Kim}, 2009)$, 우리말 조음 · 음운 검사 2(U-TAP 2, Kim, Shin, Kim, \& Ha, 2020)를 실시하였다. VRP는 모음을 가장 작은 소리부터 가장 큰 소리까지 다양한 음도에서 발성하도록 하여 화자 의 발성역치를 그래프로 나타낸 것이다(Boone et al., 2014; Ferrand, 2012). 정상적인 VRP는 완만한 타원형을 보이며, VRP의 상 곡선은 화자의 최대발성역치, 하곡선은 최소발성역치를 나타낸다 (Boone et al., 2014). 상곡선과 하곡선에 의해 만들어진 타원형의 $\mathrm{VRP}$ 는 개인의 강도와주파수 범위에서의 생리학적 한계 범위를 의 미한다. 기존 임상에서는 대상자에게 활창하기와 반음을 이용한 VRP를 실시해왔으나(Chen, 2007; Jung et al., 2019; Sanchez, Oates, Dacakis, \& Holmberg, 2014), 검사 방법에 대한 대상자의 이해도에 따라 20 분에서 1 시간 30 분까지 검사 소요시간의 편차가 크기 때문 에 후두의 극심한 피로감을 유발할 수 있다. 이에 Jung 등(2019)은 축약된 VRP 검사법을 개발하여 검사 방법의 타당성을 검증하였 다. 이 검사법은 빠른 시간 내에 가장 넓은 범위의 신뢰로운 VRP를 측정할 수 있는 것으로 밝혀져 본 연구에서는 축약된 VRP를 실시 하였다.

본 연구에서는 보기가 없는 조건의 단음절 말지각검사(Lee et al., 2009)를 사용하였다. 해당 검사는 어휘 친숙도(vocabulary familarity)와 음성적 균형(phonetic balancing)을 고려하여 개발되었으 며, 목록 간 동질성, 난이도의 동일성, 타당도와 신뢰도가 확보되어 여러 선행연구에서 널리 사용되고 있다(Yoon, 2018). 총 2개의 목 록으로 구성되어 있으며, 각 목록마다 50 개의 단음절어가 포함되 어 있다. 본 연구에서는 2 개의 목록 중 목록 1 을 사용하여 단음절 말지각 음소 점수를 산출하였다.

\section{연구절차}

모든 실험은 배경소음이 $40 \mathrm{~dB}$ 이하인 조용한 방에서 연구자와 대상자가 일대일로 실시하였고, 과제 시행 순서는 항상 동일하게 진 행하였다. 인공와우이식 청년은 단음절 말지각검사(Lee et al., 2009), 우리말 조음·음운 검사(U-TAP 2, Kim et al., 2020), VRP 순으로 실시하였고, 정상 청력 청년은 VRP만 실시하였다.

U-TAP 2는 지침서의 방법대로 실시하였다. 단음절 말지각검사 는 대상자에게 입모양을 가리고 단어를 청각적으로 제시하였으며, 대상자가 들은 단어를 따라 말하거나 종이에 적도록 하였다. 이후 10 분의 휴식을 취하고 VRP를 실시하였다. 
$\mathrm{VRP}$ 실시를 위하여 대상자는 마이크 앞에 자리하고 연구자는 대상자 맞은편에 위치하였다. /a/ 모음 발성 시 음성 녹음은 Computerized Speech Lab (CSL; Model 4150B, Kay Pentax)의 VRP 프 로그램을 사용하였다. 녹음의 샘플링 속도(sampling rate)는 44,100 $\mathrm{Hz}$ 이며, 양자화(quantization)는 $16 \mathrm{bit}$ 로 하였다. 녹음 시 공기역학 적인 소음을 감소시키기 위해 대상자의 입과 마이크는 $45^{\circ}$ 각도로 $10 \mathrm{~cm}$ 의 거리에 위치하였으며(Choi, 2013), 마이크는 단일지향성 콘덴서 마이크(유트렌드, UM300)를 사용하였다. VRP 디스플레 이 화면이 시각적 피드백으로 작용하는 것을 방지하기 위해 대상자 가 화면을 보지 못하도록 가리고 청각에만 의존하도록 하여 1 차 $\mathrm{VRP}$ 를 실시하였다. 즉, 연구자는 대상자가 자신의 청력에 의존하 여 청각적 피드백을 통해 1 차 $\mathrm{VRP}$ 를 실시하도록 하였다.

본 연구에서 사용한 축약된 $\mathrm{VRP}$ 는 정상 청력 청년의 지정된 기 준음 7 개(남성)와 9 개(여성)를 건반음과 모델링을 통해 대상자에게 제공하여 제시된 음도에서 다양한 강도로 모음 /a/를 발성하도록 하였다(Jung et al., 2019). 인공와우이식 청년의 경우, 정상 청력 청 년에 비해 발화 기본주파수가 20-100 Hz 이상 높다는 연구결과 (Gilbert \& Campbell, 1980; Huh \& Jeong, 1997)가 밝혀졌으나, 정 상 청력 청년과의 음성조절능력 비교를 위해 동일한 기준음을 사 용하여 축약된 $\mathrm{VRP}$ 를 수행하였다. 남성의 경우, 남성의 평균 기본 주파수인 $110 \mathrm{~Hz}$ 를 검사 시작 기준음으로 지정하였다. $110 \mathrm{~Hz}$ 에 해당하는 건반음을 제시하여 편안한 /a/ 발성을 유도한 뒤, 점진적 으로 강도를 감소시키며 본인이 낼 수 있는 가장 낮은 강도까지 발 성하도록 하였다. 이어서 제시된 자극음과 동일한 음도를 편안하게 발성하도록 유도한 뒤 점진적으로 강도를 증가시키며 본인이 낼 수 있는 가장 높은 강도까지 발성하도록 하였다. 그다음, $110 \mathrm{~Hz} \rightarrow$ $82.4 \mathrm{~Hz} \rightarrow 61.7 \mathrm{~Hz}$ 로 음을 낮추며 각 음마다 낮은 강도부터 높은 강 도까지 발성하도록 하였고, 이어서 $110 \mathrm{~Hz} \rightarrow 220 \mathrm{~Hz} \rightarrow 440 \mathrm{~Hz} \rightarrow$ $659.3 \mathrm{~Hz} \rightarrow 880 \mathrm{~Hz}$ 로 음을 높이며 각 음마다 낮은 강도에서 높은 강도까지 발성하도록 하였다. 이때, 진성구(modal register)를 통해 발성하도록 하였고, 대상자의 음도 일탈이 일어나는 시점을 생리학 적 발성역치로 간주하였다. 대상자가 가성을 사용하면 신체적 및 언어적 촉구와 단서를 제공하여 진성구 사용을 유도하였다. 여성의 경우, 남성보다 음역대가 넓어 총 9 개의 기준음을 제시하였으며, 여 성의 평균 기본주파수인 $220 \mathrm{~Hz}$ 를 검사 시작 기준음으로 지정하 였다. 이외에는 남성과 동일한 방법으로 실시하였으며, 기준음 9 개 는 $146.8 \mathrm{~Hz}, 174.6 \mathrm{~Hz}, 220 \mathrm{~Hz}, 440 \mathrm{~Hz}, 659.3 \mathrm{~Hz}, 880 \mathrm{~Hz}, 1,046.5$ $\mathrm{Hz}, 1,318.5 \mathrm{~Hz}, 1,568 \mathrm{~Hz}$ 이다. 과제 중 대상자가 원할 때마다 물을 충분히 섭취하도록 하였다. 1 차 VRP 수행 후, 10 분의 휴식을 취하 며 대상자에게 'Voice tools' 애플리케이션이 음도와 강도에 대한 시
각적 피드백을 제공한다는 사실에 대해 충분히 설명하였다. 연구방 법에 대한 이해를 돕기 위해 연구자는 대상자에게 모델링을 제공하 였으며, 대상자가 완벽히 이해하였을 때 연구자의 태블릿 2개를 이 용해 각각 음도와 강도에 대한 시각적 피드백을 제공하며 2차 VRP 를 실시하였다(Appendix 2). 2차 VRP는 대상자가 자신의 청각적 피드백과 태블릿을 통해 제시되는 시각적 피드백을 보며 실시하도 록 하였다.

\section{자료분석}

VRP 프로그램에서 대상자의 최저 및 최고주파수, 주파수 범위, 최소 및 최대강도, 강도 범위를 산출하였다. 음성역동면적과 기울 기는 MATLAB을 사용하여 산출하였다. MATLAB (R2020b, Mathworks)이란 많은 수의 수학, 통계 및 엔지니어링 함수를 통해 데이 터 수집 및 분석부터 응용프로그램 개발에 이르기까지 각종 공학 분야에 폭넓게 사용되고 있는 테크니컬 컴퓨팅 언어를 말한다. 본 연구에서는 각 대상자가 수행한 VRP 이미지를 MATLAB에서 디 지털화하여 이진화 처리하였다. 영상의 이진화는 컬러 데이터에 임 계값(threshold)을 적용하여 각 픽셀값을 0 또는 1 로 나타낸 것이 다(Kim, 2003; Ko, 2008). 본 연구에서는 이진화된 VRP 이미지에 서 Green 성분만 추출하였고, 이 성분들의 픽셀 개수를 산출하여 음성역동면적을 구하였다(Figure 1). 음성역동면적은 음성조절능 력을 평가하는 첫 번째 측정변수로서, 화자가 얼마나 넓은 범위의 음도 및 강도에서 자신의 음성을 역동적으로 조절하여 발성하였는 가를 나타낸다. 이미지에 나타난 픽셀 개수가 많고 범위가 넓을수 록 음성역동면적이 크고, 픽셀 개수가 적고 폭이 좁을수록 음성역

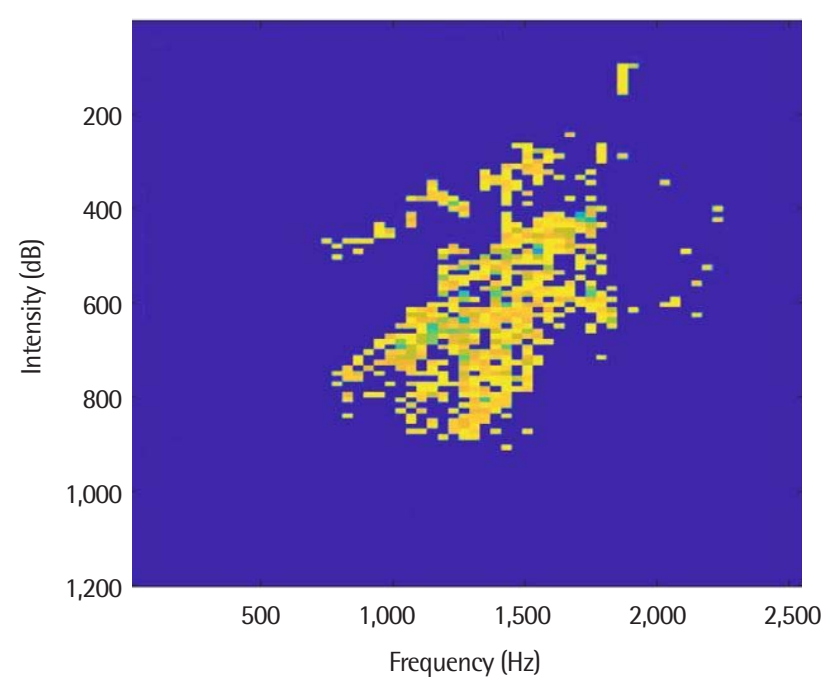

Figure 1. Distribution of voice dynamic area. 
동면적이 작은 것으로 해석할 수 있다. 즉, 음성역동면적 값이 클수 록 넓은 주파수 범위에서 다양한 강도로 자신의 음성을 역동적으 로 조절하는 것을 의미한다.

$\mathrm{VRP}$ 기울기란 음성조절능력을 평가하는 두 번째 측정변수이다. 본 연구에서는 MATLAB에서 VRP의 픽셀 데이터를 X축과 $\mathrm{Y}$ 축의 2차원 평면상에 올린 뒤 선형회귀식을 도출하여 VRP 기울기를 산 출하였다(Figure 2). 정상적인 VRP는 완만한 타원형을 보이며(Boone et al., 2014), 기울기 값이 클수록 병리적인 음성을 가진 것으로 평 가한다. 따라서 제한된 주파수 범위에서 큰 강도 범위로 발성할수 록 기울기는 가파르고, 적절한 주파수 범위와 강도 범위로 발성할 수록기울기가 완만한 것으로 해석할 수 있다.

\section{자료의 통계적 처리}

본 연구에서는 IBM SPSS statistics 26.0 (IBM-SPSS Inc., Chicago, IL, USA)을 이용하여 자료를 분석하였다. 먼저, 시각적 피드백 유무에 따라 음도 관련 측정치(최대주파수, 최저주파수, 주파수 범 위), 강도 관련 측정치(최대강도, 최소강도, 강도 범위), 음성역동면 적, VRP 기울기에서 집단 간 차이가 유의한지 알아보기 위하여 이 원혼합분산분석(two-way mixed ANOVA)을 실시하였다. 집단(인 공와우이식 청년, 정상 청력 청년)은 피험자 간 요인(between subjects factors)으로, 자극(청각, 시각-청각)은 피험자 내 요인(within subjects factors)으로 설정하였다. 둘째, 인공와우이식 청년의 인공 와우이식 연령, 인공와우 착용기간, 단음절 말지각점수, 자음정확 도와 음성조절능력 변수(음성역동면적, $\mathrm{VRP}$ 기울기) 간 상관관계 를 알아보기 위해 피어슨 이변량 상관분석(Pearson correlation)을 실시하였다. 셋째, 인공와우이식 청년 집단 내에서 선천성 농인과 후천성 농인의 음성역동면적 및 VRP 기울기 값에 유의한 차이가 있는지 알아보기 위해 맨휘트니 검정(Mann-Whitney U test)을 실 시하였다. 통계적 유의수준은.05 수준에서 검정하였다.

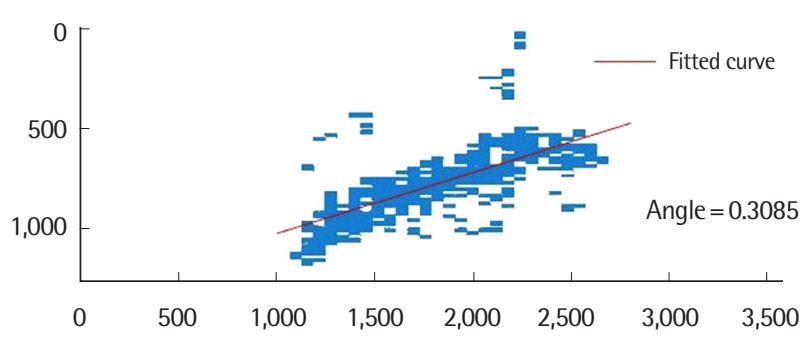

Figure 2. Distribution of voice range profile slope.

\section{연구결과}

\section{시각적 피드백 유무에 따른 집단 간 음도 관련 측정치 차이 분석}

음도 관련 측정치에 대한 두 집단의 기술통계 값을 살펴본 결과, 정상 청력 청년이 인공와우이식 청년보다 최대주파수가 더 높은 것 으로 나타났으며, 최저주파수는 더 낮은 것으로 나타났다. 따라서 인공와우이식 청년보다 정상 청력 청년의 주파수 범위가 큰 것으로 나타났다(Table 2).

시각적 피드백 유무에 따른 VRP 음도 관련 측정치에서 집단 간 차이가 있는지 알아보기 위해 이원혼합분산분석(two-way mixed ANOVA)을 실시하였다. 집단과 자극(청각, 시각-청각)을 독립변수 로 하고, 최대주파수, 최소주파수, 주파수 범위를 종속변수로 한 이 원혼합분산분석 결과는 Table 3에 제시하였다.

최대주파수에 대하여 인공와우이식 청년 집단과 정상 청력 청년 집단 간 주효과가 통계적으로 유의하지 않았으나 $\left(F_{(1,22)}=1.064\right.$, $p>.05)$, 자극에 대한주효과는 통계적으로 유의하였다 $\left(F_{(1,22)}=10.442\right.$, $p<.005)$. 집단과 자극 간 이차 상호작용은 통계적으로 유의하지 않은 것으로 나타났다 $\left(F_{(1,22)}=.000, p>.05\right)$.

최소주파수에 대하여 인공와우이식 청년 집단과 정상 청력 청년 집단 간 주효과가 통계적으로 유의하지 않았으나 $\left(F_{(1,22)}=1.463, p>\right.$ $.05)$, 자극에 대한 주효과는 통계적으로 유의하였다 $\left(F_{(1,22)}=5.759\right.$, $p<.05)$. 집단과 자극 간 이차 상호작용은 통계적으로 유의하지 않 은 것으로 나타났다 $\left(F_{(1,22)}=.098, p>.05\right)$.

주파수 범위에 대하여 인공와우이식 청년 집단과 정상 청력 청 년 집단 간 주효과가 통계적으로 유의하지 않았으나 $\left(F_{(1,22)}=1.846\right.$, $p>.05)$, 자극에 대한주효과는 통계적으로 유의하였다 $\left(F_{(1,22)}=11.852\right.$, $p<.005)$. 집단과 자극 간 이차 상호작용은 통계적으로 유의하지 않은 것으로 나타났다 $\left(F_{(1,22)}=.000, p>.05\right)$.

Table 2. Descriptive statistics on the pitch measurements $(\mathrm{Hz})$ for each group with or without visual feedback

\begin{tabular}{llll}
\hline Feedback & \multicolumn{1}{c}{ Pitch measurements } & \multicolumn{1}{c}{$\mathrm{Cl}(\mathrm{N}=12)$} & \multicolumn{1}{c}{$\mathrm{NH}(\mathrm{N}=12)$} \\
\hline Auditory only & Maximum frequency & $542.54(196.03)$ & $629.22(188.50)$ \\
& Minimum frequency & $159.09(43.54)$ & $138.20(42.05)$ \\
Visual- & Frequency range & $383.41(179.66)$ & $491.02(177.98)$ \\
auditory & Maximum frequency & $639.62(302.96)$ & $727.54(167.74)$ \\
& Minimum frequency & $151.26(40.48)$ & $132.17(38.15)$ \\
& Frequency range & $488.36(293.05)$ & $595.37(148.62)$ \\
\hline
\end{tabular}

Values are presented as mean (SD).

$\mathrm{Cl}=$ young adults with Cochlear implants; $\mathrm{NH}=$ young adults with Normal hearing 
Table 3. Results of two-way mixed ANOVA for pitch measurements

\begin{tabular}{|c|c|c|c|c|c|}
\hline Pitch measurements & Distributed source & Sum of squares & Degree of freedom & Mean square & $F$ \\
\hline \multirow[t]{7}{*}{ Maximum frequency } & Between factor & & & & \\
\hline & Group & $91,464.210$ & 1 & $91,464.210$ & 1.064 \\
\hline & Error & 1,891,386.371 & 22 & $85,972.108$ & \\
\hline & Within factor & & & & \\
\hline & Feedback & $114,545.434$ & 1 & $114,545.434$ & $10.442^{* * *}$ \\
\hline & Feedback×Group & 4.650 & 1 & 4.650 & .000 \\
\hline & Error & $241,342.422$ & 22 & $10,970.110$ & \\
\hline \multirow[t]{7}{*}{ Minimum frequency } & Between factor & & & & \\
\hline & Group & $4,796.801$ & 1 & $4,796.801$ & 1.463 \\
\hline & Error & $72,135.409$ & 22 & 3,278.882 & \\
\hline & Within factor & & & & \\
\hline & Feedback & 576.022 & 1 & 576.022 & $5.759^{*}$ \\
\hline & Feedback×Group & 9.756 & 1 & 9.756 & .098 \\
\hline & Error & $2,200.445$ & 22 & 100.020 & \\
\hline \multirow[t]{7}{*}{ Frequency range } & Between factor & & & & \\
\hline & Group & $138,206.696$ & 1 & $138,206.696$ & 1.846 \\
\hline & Error & $1,647,231.872$ & 22 & $74,874.176$ & \\
\hline & Within factor & & & & \\
\hline & Feedback & $131,419.470$ & 1 & $131,419.470$ & $11.852^{* * *}$ \\
\hline & Feedback×Group & 1.080 & 1 & 1.080 & .000 \\
\hline & Error & $243,935.376$ & 22 & $1,1087.972$ & \\
\hline
\end{tabular}

${ }^{*} p<.05,{ }^{* * *} p<.005$.

Table 4. Descriptive statistics on the intensity measurements (dB) for each group with or without visual feedback

\begin{tabular}{llrr}
\hline Feedback & \multicolumn{1}{c}{$\begin{array}{l}\text { Intensity } \\
\text { measurements }\end{array}$} & $\mathrm{Cl}(\mathrm{N}=12)$ & $\mathrm{NH}(\mathrm{N}=12)$ \\
\hline Auditory only & Maximum intensity & $117.25(7.94)$ & $120.42(8.54)$ \\
& Minimum intensity & $58.42(2.11)$ & $56.25(2.70)$ \\
& Intensity range & $58.83(8.84)$ & $64.17(9.82)$ \\
Visual-auditory & Maximum intensity & $118.17(7.81)$ & $123.67(1.16)$ \\
& Minimum intensity & $57.83(1.59)$ & $57.00(2.59)$ \\
& Intensity range & $60.33(8.02)$ & $66.67(3.09)$ \\
\hline
\end{tabular}

Values are presented as mean (SD).

$\mathrm{Cl}=$ young adults with Cochlear implants; $\mathrm{NH}=$ young adults with Normal hearing.

\section{시각적 피드백 유무에 따른 집단 간 강도 관련 측정치 차이 분석}

강도 관련 측정치에 대한 두 집단의 기술통계 값을 살펴본 결과, 정상 청력 청년이 인공와우이식 청년보다 최대강도가 더 높은 것으 로 나타났으며, 최소강도는 더 낮은 것으로 나타났다. 따라서 인공 와우이식 청년보다 정상 청력 청년의 강도 범위가 큰 것으로 나타 났다(Table 4).

시각적 피드백 유무에 따른 VRP 강도 관련 측정치에서 집단 간 차이가 있는지 알아보기 위해 이원혼합분산분석(two-way mixed
ANOVA)을 실시하였다. 집단과 자극을 독립변수로 하고, 최대강 도, 최소강도, 강도 범위를 종속변수로 한 이원혼합분산분석 결과 는 Table 5에 제시하였다.

최대강도에 대하여 인공와우이식 청년 집단과 정상 청력 청년 집 단 간 주효과가 통계적으로 유의하지 않았고 $\left(F_{(1,22)}=2.742, p>.05\right)$, 자극에 대한 주효과도 유의하지 않았다 $\left(F_{(1,22)}=3.051, p>.05\right)$. 집단 과 자극 간 이차 상호작용도 통계적으로 유의하지 않은 것으로 나 타났다 $\left(F_{(1,22)}=.957, p>.05\right)$.

최소강도에 대하여 인공와우이식 청년 집단과 정상 청력 청년 집 단 간 주효과가 통계적으로 유의하지 않았고 $\left(F_{(1,22)}=3.122, p>.05\right)$, 자극에 대한 주효과도 유의하지 않았다 $\left(F_{(1,22)}=.045, p>.05\right)$. 집단 과 자극 간 이차 상호작용도 통계적으로 유의하지 않은 것으로 나 타났다 $\left(F_{(1,22)}=2.891, p>.05\right)$.

강도 범위에 대하여 인공와우이식 청년 집단과 정상 청력 청년 집 단 간 주효과가 통계적으로 유의하지 않았고 $\left(F_{(1,22)}=3.935, p>.05\right)$, 자극에 대한 주효과도 유의하지 않았다 $\left(F_{(1,22)}=2.347, p>.05\right)$. 집단 과 자극 간 이차 상호작용도 통계적으로 유의하지 않은 것으로 나 타났다 $\left(F_{(1,22)}=.147, p>.05\right)$. 
Ji Eun Kang, et al. • The Voice Control Ability of Prelingual Deafened Young Adults with CI

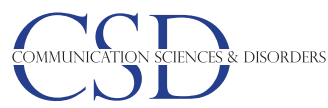

Table 5. Results of two-way mixed ANOVA for intensity measurements

\begin{tabular}{|c|c|c|c|c|c|}
\hline Pitch measurements & Distributed source & Sum of squares & Degree of freedom & Mean square & $F$ \\
\hline \multirow[t]{7}{*}{ Maximum intensity } & Between factor & & & & \\
\hline & Group & 225.333 & 1 & 225.333 & 2.742 \\
\hline & Error & $1,807.917$ & 22 & 82.178 & \\
\hline & Within factor & & & & \\
\hline & Feedback & 52.083 & 1 & 52.083 & 3.051 \\
\hline & Feedback×Group & 16.333 & 1 & 16.333 & .957 \\
\hline & Error & $241,342.422$ & 22 & $10,970.110$ & \\
\hline \multirow[t]{7}{*}{ Minimum intensity } & Between factor & & & & \\
\hline & Group & 27.000 & 1 & 27.000 & 3.122 \\
\hline & Error & 190.250 & 22 & 8.648 & \\
\hline & Within factor & & & & \\
\hline & Feedback & .083 & 1 & .083 & .045 \\
\hline & Feedback×Group & 5.333 & 1 & 5.333 & 2.891 \\
\hline & Error & 40.583 & 22 & 1.845 & \\
\hline \multirow[t]{7}{*}{ Intensity range } & Between factor & & & & \\
\hline & Group & 408.333 & 1 & 408.333 & 3.935 \\
\hline & Error & $2,282.667$ & 22 & 103.758 & \\
\hline & Within factor & & & & \\
\hline & Feedback & 48.000 & 1 & 48.000 & 2.347 \\
\hline & Feedback×Group & 3.000 & 1 & 3.000 & .147 \\
\hline & Error & 450.000 & 22 & 20.455 & \\
\hline
\end{tabular}

Table 6. Descriptive statistics on the voice dynamic area for each group with or without visual feedback

\begin{tabular}{lcc}
\hline Feedback & \multicolumn{1}{c}{$\mathrm{Cl}(\mathrm{N}=12)$} & $\mathrm{NH}(\mathrm{N}=12)$ \\
\hline Auditory only & $280,563.00(76,732.88)$ & $491,079.42(146,760.88)$ \\
Visual-auditory & $387,634.75(127,817.54)$ & $523,934.67(142,415.99)$ \\
\hline
\end{tabular}

$\mathrm{Cl}=$ young adults with Cochlear implants; $\mathrm{NH}=$ young adults with Normal hearing.

\section{시각적 피드백 유무에 따른 집단 간 음성역동면적 차이 분석}

음성역동면적에 대한 두 집단의 기술통계 값을 살펴본 결과, 정 상 청력 청년이 인공와우이식 청년보다음성역동면적이 더 넓은 것 으로 나타났다(Table 6). 인공와우이식 청년과 정성 청력 청년의 음 성역동면적의 분포 예시는 Figure 3에 제시하였다

시각적 피드백 유무에 따라 집단 간 음성역동면적의 차이가 있 는지 알아보기 위해 집단과 자극을 독립변수로 하고, 음성역동면 적을 종속변수로 한 이원혼합분산분석(two-way mixed ANOVA) 을 실시하였다(Table 7). 그 결과, 집단과 자극 간 이차 상호작용은 통계적으로 유의하였다 $\left(F_{(1,22)}=7.293, p<.05\right)$. 즉, 인공와우이식 청 년 집단은 정상 청력 청년보다 시각적 피드백이 있을 때 음성역동면 적 변화가 더 큰 것에 기인하여 집단과 자극 간 이차 상호작용이 유 의한 것으로 나타났다(Figure 4). 집단과 자극 간 상호작용으로 각 집단 내 자극에 따른 음성역동면적의 차이를 비교하기 위하여 대
Table 7. Results of two-way mixed ANOVA for voice dynamic area

\begin{tabular}{lcccc}
\hline Distributed source & $\begin{array}{c}\text { Sum of } \\
\text { squares }\end{array}$ & $\begin{array}{c}\text { Degree of } \\
\text { freedom }\end{array}$ & $\begin{array}{c}\text { Mean } \\
\text { square }\end{array}$ & $F$ \\
\hline Between factor & & & & \\
$\quad$ Group & $3.608 \mathrm{E}+11$ & 1 & $3.608 \mathrm{E}+11$ & $12.126^{* *}$ \\
$\quad$ Error & $6.547 \mathrm{E}+11$ & 22 & $2.976 \mathrm{E}+10$ & \\
Within factor & & & & \\
$\quad$ Feedback & $5.874 \mathrm{E}+10$ & 1 & $5.874 \mathrm{E}+10$ & $25.924^{* * *}$ \\
Feedback×Group & $1.652 \mathrm{E}+10$ & 1 & $1.652 \mathrm{E}+10$ & $7.293^{*}$ \\
Error & $4.985 \mathrm{E}+10$ & 22 & $2,265,844,999$ & \\
\hline
\end{tabular}

응표본 $t$-검정을 실시한 결과, 인공와우이식 청년 집단에서 시각적 피드백 유무에 따른 음성역동면적의 차이가 통계적으로 유의하였 다 $\left(t_{(11)}=-5.258, p<.001\right)$. 정상 청력 청년 집단에서도 시각적 피드 백 유무에 따른 음성역동면적의 차이가 통계적으로 유의하였다 $\left(t_{(11)}=-2.958, p<.05\right)$.

\section{시각적 피드백 유무에 따른 집단 간 VRP 기울기 차이 분석}

Table 8에 나타난 바와 같이 VRP 기울기에 대한 두 집단의 기술 통계 값을 살펴본 결과, 인공와우이식 청년이 정상 청력 청년보다 기울기가 더 가파른 것으로 나타났다(Figure 5).

시각적 피드백 유무에 따라 집단 간 VRP 기울기의 차이가 있는 


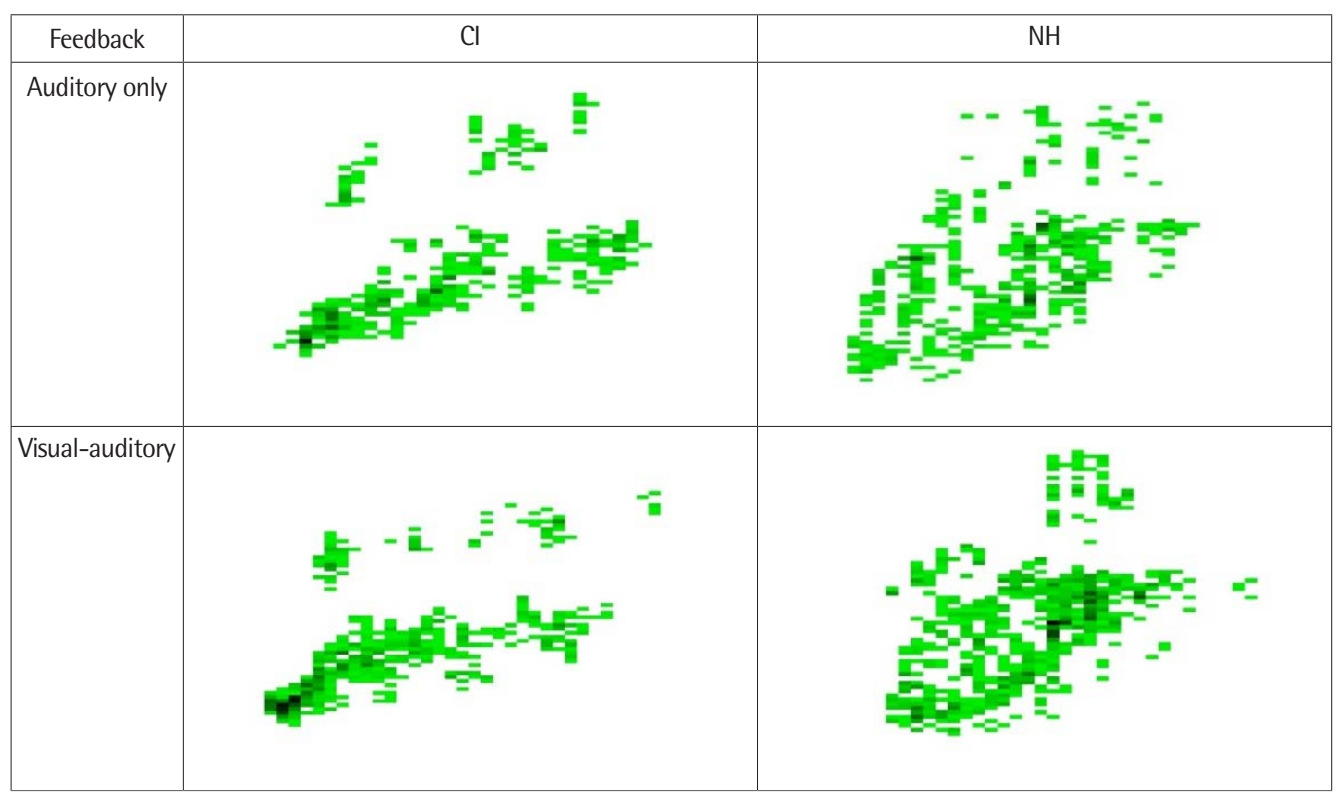

Figure 3. Example of Voice dynamic area for each group.

$\mathrm{Cl}=$ young adults with cochlear implants; $\mathrm{NH}=$ young adults with normal hearing.

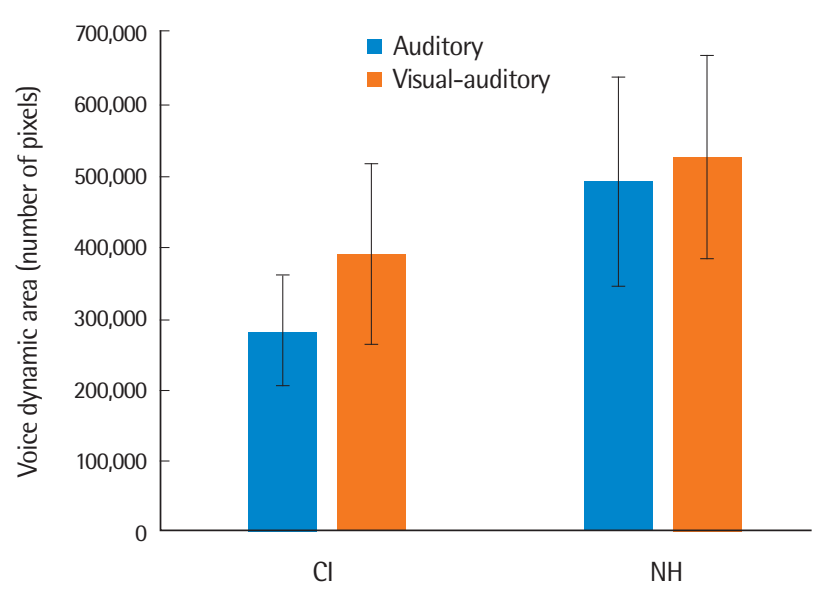

Figure 4. Voice dynamic area between groups with or without visual feedback. $\mathrm{Cl}=$ young adults with cochlear implants; $\mathrm{NH}=$ young adults with normal hearing

Table 8. Descriptive statistics on the VRP slope for each group with or without visual feedback

\begin{tabular}{lcc}
\hline Feedback & $\mathrm{Cl}(\mathrm{N}=12)$ & $\mathrm{NH}(\mathrm{N}=12)$ \\
\hline Auditory only & $.48(.27)$ & $.32(.09)$ \\
Visual-auditory & $.44(.25)$ & $.29(.09)$ \\
\hline
\end{tabular}

Values are presented as mean (SD).

$\mathrm{Cl}=$ young adults with cochlear implants; $\mathrm{NH}=$ young adults with normal hearing; $\mathrm{VRP}=$ voice range profile.

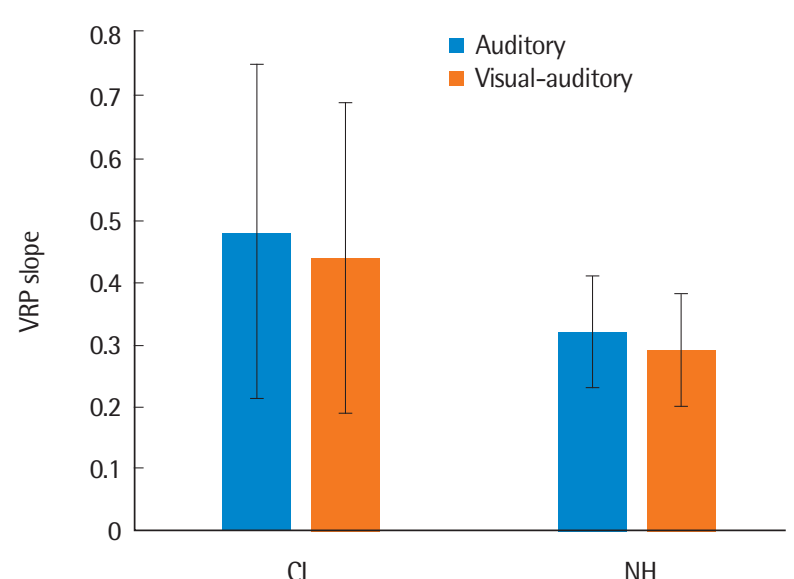

Figure 5. VRP slope between groups with or without visual feedback. $\mathrm{Cl}=$ young adults with cochlear implants; $\mathrm{NH}=$ young adults with normal hearing; $\mathrm{VRP}=$ voice range profile.

지 알아보기 위해 집단과 자극을 독립변수로 하고, VRP 기울기를 종속변수로 한 이원혼합분산분석(two-way mixed ANOVA)을 실 시하였다(Table 9). 인공와우이식 청년 집단과 정상 청력 청년 집단 간 주효과가 통계적으로 유의하지 않았다 $\left(F_{(1,22)}=3.715, p>.05\right)$. 자 극에 대한 주효과가 통계적으로 유의하였다 $\left(F_{(1,22)}=6.541, p<.05\right)$. 집단과 자극 간 이차 상호작용은 통계적으로 유의하지 않은 것으로 나타났다 $\left(F_{(1,22)}=.122, p>.05\right)$. 
Table 9. Results of two-way mixed ANOVA for VRP slope

\begin{tabular}{lcccc}
\hline Distributed source & $\begin{array}{c}\text { Sum of } \\
\text { squares }\end{array}$ & $\begin{array}{c}\text { Degree of } \\
\text { freedom }\end{array}$ & $\begin{array}{c}\text { Mean } \\
\text { square }\end{array}$ & $F$ \\
\hline Between factor & & & & \\
$\quad$ Group & .276 & 1 & .276 & 3.715 \\
$\quad$ Error & 1.635 & 22 & .074 & \\
Within factor & & & & \\
Feedback & .016 & 1 & .016 & $6.541^{*}$ \\
Feedback×Group & .000 & 1 & .000 & .122 \\
Error & .054 & 22 & .002 & \\
\hline
\end{tabular}

$\mathrm{VRP}=$ voice range profile.

${ }^{*} p<.05$.
Table 10. Results of Pearson correlation coefficients between cochlear information, basic assessment scores and voice control variables

\begin{tabular}{|c|c|c|c|c|c|}
\hline Distributed source & $\mathrm{Cl}$ age & $\begin{array}{l}\mathrm{Cl} \text { wearing } \\
\text { period }\end{array}$ & $\begin{array}{l}\text { Monosyl- } \\
\text { lable per- } \\
\text { ception } \\
\text { scores }\end{array}$ & $\begin{array}{c}\text { Word } \\
\text { consonant } \\
\text { accuracy }\end{array}$ & $\begin{array}{c}\text { Sentence } \\
\text { consonant } \\
\text { accuracy }\end{array}$ \\
\hline \multicolumn{6}{|l|}{ Auditory } \\
\hline Voice dynamic area & -.200 & .111 & .054 & -.190 & -.215 \\
\hline VRP slope & .362 & .219 & -.300 & $-.832^{* *}$ & $-.919^{* *}$ \\
\hline \multicolumn{6}{|l|}{ Visual-auditory } \\
\hline Voice dynamic area & .060 & .219 & -.095 & -.232 & -.011 \\
\hline VRP slope & .476 & -.055 & .102 & $-.818^{* *}$ & $-.876^{* *}$ \\
\hline
\end{tabular}

Table 11. Results of Mann-Whitney U test for voice dynamic are and VRP slope

\begin{tabular}{|c|c|c|c|c|c|c|c|}
\hline & & \multicolumn{2}{|c|}{ Congenital $\mathrm{Cl}(\mathrm{N}=7)$} & \multicolumn{2}{|c|}{ Acquired $\mathrm{Cl}(\mathrm{N}=5)$} & \multirow{2}{*}{$Z$} & \multirow{2}{*}{$p$} \\
\hline & & M & SD & M & SD & & \\
\hline \multirow[t]{2}{*}{ Auditory only } & VDA & $299,303.00$ & $83,154.947$ & $254,327.00$ & $65,914.446$ & -1.056 & .291 \\
\hline & VRP slope & .5429 & .34779 & .3940 & .06107 & -.568 & .570 \\
\hline \multirow[t]{2}{*}{ Visual-auditory } & VDA & $380,872.86$ & $129,955.050$ & $397,101.40$ & $139,295.122$ & -.244 & .808 \\
\hline & VRP slope & .47 & .31817 & .3960 & .13353 & -.081 & .935 \\
\hline
\end{tabular}

Values are presented as mean (SD).

$\mathrm{Cl}=$ cochlear implants; $\mathrm{VDA}=$ voice dynamic area; $\mathrm{VRP}=$ voice range profile.

\section{인공와우 관련 정보 및 기초검사 점수와 음성조절능력 변수 간 상관관계 분석}

인공와우이식 청년 집단의 인공와우이식 연령, 인공와우 착용기 간, 단음절 말지각점수, 단어 및 문장 자음정확도와 음성조절능력 변수(음성역동면적, VRP 기울기) 간 상관관계를 알아보기 위해 Pearson 상관분석을 실시하였다. 상관관계 분석 결과, 단어 수준에 서의 자음정확도와 청각적 피드백 제공시의 VRP 기울기 간에 유 의한 상관관계 $(r=-.832, p<.01)$ 가 나타났으며, 문장 수준에서의 자음정확도와 청각적 피드백 제공시의 VRP 기울기 간에 유의한 상관관계가 나타났다 $(r=-.919 p<.01)$. 또한, 단어 자음정확도와 시-청각적 피드백이 제공되었을 때 VRP 기울기 간 유의한 상관관 계 $(r=-.818, p<.01)$ 가 나타났고, 문장 자음정확도와 시-청각적 피 드백이 제공되었을 때 VRP 기울기 간 유의한 상관관계 $(r=-.876$, $p<.01$ )가 나타났다(Table 10).

\section{선천성-후천성 인공와우이식 청년의 음성역동면적 및 VRP 기울기 차이 분석}

인공와우이식 청년 집단 내에서 선천성 농인과 후천성 농인의 음성역동면적 및 VRP 기울기 값이 유의한 차이가 있는지 알아보 기 위해 맨휘트니 검정(Mann-Whitney U test)을 실시하였다. 그 결
과, 선천성 농인과 후천성 농인의 음성역동면적 및 VRP 기울기 값 은 유의한차이가 없는 것으로 나타났다(Table 11).

\section{논의 및 결론}

본 연구에서는 시각적 피드백 유무에 따라 두 집단 간 음도와 강 도를 포함한음성조절의 역동성에 차이가 있는지 알아보고자 하였 다. 또한, 인공와우이식 청년의 음성조절능력과 관련 있는 변인이 무엇인지 확인하고, 시각적 피드백 유무에 따라 선천성 농인과 후 천성 농인 간 음성조절능력에 차이가 있는지 알아보고자 하였다.

먼저 선행연구와 같이 음도 관련 측정치(최대주파수, 최소주파 수, 주파수 범위)와 강도 관련 측정치(최대강도, 최소강도, 강도 범 위) 각각을 단독으로 분석한 결과, 인공와우이식 청년 집단과 정상 청력 청년 집단 간 차이는 통계적으로 유의하지 않았다. 시각적 피 드백 유무에 따른 음도 관련 측정치의 차이는 통계적으로 유의하 였으나, 강도 관련 측정치는 시각적 피드백 유무에 따른 차이가 통 계적으로 유의하지 않았다. 이러한 결과는 시각적 피드백이 음도를 개선하는 데 효과적이라는 선행연구(Euh \& Yoon, 2005)와 일치한 다. 또한 음도는 인공와우의 기기적 한계로 인해 인공와우이식 청 년이 음도 산출에서 한계를 보일 수 있지만(Snow \& Ertmer, 2012), 
강도는 인공와우이식 후 가장 먼저 음성적 개선을 보여 정상 청력 청년과 유사해지는 변인으로(Campisi et al., 2005), 이식 후 2년 이 상 인공와우를 착용하였을 때 정상 청력 청년과 유의한 차이를 보 이지 않는다고 언급한 선행연구(Bae, 2011; Yoon, 2006) 결과를 뒷 받침한다. 그러나 본 연구 결과 해석 시 주의가 따른다. 본 연구에서 두 집단 간 강도 관련 측정치의 차이가 없는 것으로 나타났으나, 질 적 분석 시 정상 청력 청년보다 인공와우이식 청년이 강도를 조절 하는 과정에서 한계가 나타났다. VRP 수행 시, 인공와우이식 청년 은 정상 청력 청년처럼 큰 강도와 작은 강도에서 발성하는 것이 가 능하였으나, 점진적으로 강도를 증가시킬 때와 점진적으로 강도를 감소시킬 때 세밀하게 강도를 조절하는 것에 어려움을 보였다. 즉, 강도를 증감하는 과정에서 중간 강도로 발성하는 것에 어려움을 보여 VRP 화면에서 두 개의 타원 사이에 빈 공간이 만들어지는 양 상을 보였다. 큰 강도의 음성을 산출하기 위해서는 높은 성문하압 이 요구되며, 큰 강도에서 작은 강도로 감소할 때는 호흡 관련 근육 의 세밀한 조절이 필요하다(Boone et al., 2014; Titze, 1994). 본 연구 에서 인공와우이식 청년은 강도를 감소시키거나 증가할 때 필요한 폐압을 조절하는 근육과 후두 주변 근육의 수축과 이완이 원활하 지 못하여 갑작스러운 강도 증감을 보였던 것으로 보인다(Spector et al., 1979). 본 연구의 결과는 음도와 강도 관련한 단독 측정치만 으로 인공와우이식 청년의 음성조절능력을 단정 지을 수 없다는 것을 시사하며, 음성조절능력을 측정할 새로운 파라미터의 필요성 이 제기된다.

본 연구에서 음성역동면적에 대한 이원혼합분산분석 결과, 집단 과 자극 간 이차상호작용이 통계적으로 유의하였다. 즉, 정상 청력 청년보다 인공와우이식 청년 집단에서 시-청각적 피드백이 제공되 었을 때 음성역동면적의 변화가 더 컸던 것에 기인하여 집단과 자 극 간 이차 상호작용이 유의한 것으로 나타났다. 본 연구에서 음도 와 강도 각각 단독 측정치에 대해 비교하였을 때 인공와우이식 청 년과 정상 청력 청년 간 유의한 차이가 없었다. 이는 장기간 인공와 우를 착용한 청년은 정상 청력 청년과 같이 음도와 강도에 대한 개 념을 학습하여 안정된 음성을 산출하므로 집단 간 차이가 없다는 선행연구 결과(Cerçi, Kandoğan, Olgun, Gültekin, Alper, 2006; Hamzavi et al., 2000; Yoon, 2006)와 일치한다. 그러나 본 연구에서 는 음성조절능력에 대해 인공와우이식 청년과 정상 청력 청년 간 유의한 차이가 나타나 기존연구 결과와 차이가 있으며, $\mathrm{VRP}$ 를 사 용하여 음도와 강도를 동시에 조절하는 음성의 역동적 범위를 살 펴보았다는 점에서 의의가 있다. 즉, 본 연구결과는 음도와 강도 각 각의 단일 측정치만으로는 인공와우이식 청년의 음성조절능력을 측정하는 데 한계가 있다는 점을 시사하며, 음성조절능력을 측정
하는 새로운 변수인 음성역동면적의 유용성을 시사한다.

난청 집단에서 교정 청력이 26-40 dB인 경도 청력손실은 음성에 큰 영향을 미치지 않으며 인공와우이식 후 청각적 피드백이 증가하 여 청력이 안정되면 음도나 강도에 대한 중재 없이 안정된 음성을 보인다는 연구결과가 보고되었으나(Hamzavi et al., 2000; Yoon et al., 2013), 인공와우이식 청년은 음도와 강도를 함께 조절하며 다양 한 범위에서 역동적인 음성을 산출하는 것에는 한계가 있었던 것 으로 추론할 수 있다. 정상적인 발성은 후두내근의 연속적인 운동 에 의해 성대가 내·외전하고 후두외근이 성대의 길이 및 긴장도에 변화를 주어 일어난다(Shin et al., 2014). 성대의 불충분한 폐쇄로 인해 성도 밖으로 기류가 누출되면 충분한 성문하압이 형성되지 못하여 발성에 부정적인 영향을 미치고 말 명료도를 저하시킨다 (Pyo, 2007). 11세에서 16세 사이의 청소년기에는 후두가 하강하며 성대 길이가 증가하는 변성기를 경험하고 초기 청년과 비슷한 음성 을 가지게 되는데(Boone et al., 2014; Kim, 2008; Pedersen, 1993), 본 연구의 대상자들은 만 7세 이전에 청력손실을 경험하여 인공와 우를 착용하였다는 특성이 있다. 인공와우는 어음처리기(speech processor)로 의사소통 시 사용하는 말소리의 음역대를 효율적으 로 처리하도록 개발된 기계로, 시간상으로 변화하는 말소리의 미세 구조 신호를 세밀하게 전달하지 못하며 말소리 이외의 자극을 효율 적으로 처리하는 데 한계가 있다(Shannon, Zeng, Kamath, Wygonski, \& Ekelid, 1995; Smith, Delgutte, \& Oxenham, 2002). 따라 서 청소년 및 성인기까지 인공와우를 지속적으로 착용해왔음에도 본 연구의 대상자는 인공와우의 기기적 제한성으로 인하여 역동적 인 음성조절이 어려웠던 것으로 사료된다. 또한 언어, 말, 후두 주변 근육 등 발달이 모두 이루어지기 전 발생한 청력손실은 음성을 세 밀하게 조절하고 사용하는 능력의 발달을 저해하였고, 인공와우로 인해 제한된 청각적 피드백을 수용하며 음성조절에 관여하는 근육 과 신경계의 발달이 완성되어 부적절한 음성조절이 학습된 것으로 해석할 수 있다. 즉, 신체적· 정신적으로 성장하는 과정에서 적절하 게 음성을 사용하지 않으면 성대 긴장, 성문하압과 후두근의 미숙 한 조절 등 발성 기관의 불안정한 기능으로 음성 문제가 나타날 수 있으며(Boone et al., 2014), 특히 역동적인 음성조절을 위해 후두가 발달하는 기간 동안 정상적인 청각적 피드백이 필수적이라는 것을 시사한다.

$\mathrm{VRP}$ 기울기의 차이를 분석한 결과, 두 집단 간 통계적으로 유의 한 차이는 없었다. 시각적 피드백 유무에 따른 VRP 기울기의 차이 를 분석한 결과, 청각적 피드백만 제공되었을 때보다 시-청각적 피 드백이 제공되었을 때 기울기가 유의하게 작은 것으로 나타났다. 본 연구결과는 시각적 피드백이 음성을 조절하는 데 효과적이라는 
것을 시사한다. 본 연구에 참여한 인공와우이식 청년은 모두 언어 습득 전에 농이 되었지만, 청각장애 발병 시점과 원인은 상이하다. 즉, 대상자 중 5명은 후천성 농이며, 나머지 7명은 선천성 농에 속하 는 경우에 해당하였다. 본 연구에서 생애 초기의 듣기 경험이 음성 조절능력에 미치는 영향을 추가적으로 분석한 결과, 선천성 농인 과 후천성 농인의 음성역동면적 및 VRP 기울기는 유사한 경향을 보였다. 이러한 결과는 인공와우이식 청년의 음성조절능력 발달을 위해 발달기간 동안 지속적인 청각적 피드백이 제공되어야 한다는 것을 상기시킨다. 또한, 이러한 결과는 듣기경험이 인공와우이식 청 년의 언어, 말, 음성 등 전반적인 발달에 매우 중요하지만, 정상적인 듣기경험이 후두발달 완성기까지 지속되지 못하면 성대를 조절하 는 후두 주변 신경근육의 협응 능력이 온전히 발달하지 못하고 정 체되는 결과를 초래하는 것으로 해석할 수 있다. 본 연구는 청력손 실 이전에 정상적인 듣기 경험이 있는 후천성 농인 또한 언어청능재 활이 지속되어야 한다는 점을 강조하여 임상적 의의가 높다. 다만, 음성역동면적과 VRP 기울기는 상호보완적인 관계로 결과를 분석 할 때 주의가 요구된다. 청각적 피드백만 제공되었을 때 선천성 집 단이 후천성 집단보다 더 큰 음성역동면적을 보였으나, VRP 기울 기는 더 가파른 것으로 나타났다. 본 연구의 정상 청력 성인의 VRP 기울기 평균값 $(\mathrm{M}=.32)$ 과 비교하였을 때 선천성 집단보다 후천성 집단이 정상 청력 성인과 더 유사한 것으로 나타나 안정적인 음성 조절능력을 보이는 것으로 해석할 수 있다. 두 집단 모두 시각적 피 드백 유무에 따라 VRP 기울기의 변화가 유의하지 않았으나, 음성 역동면적에서는 시-청각적 피드백이 제공되었을 때 선천성 집단보 다 후천성 집단에서 더 큰 변화 양상을 보였다. 본 결과는 인공와우 이식 청년의 역동적인 음성조절능력을 측정하는 데 있어서 음성역 동면적과 VRP 기울기를 단독으로 다루는 것에 대한 유의점을 시 사한다. 따라서 음성역동면적과 VPR 기울기를 함께 고려한 전반적 인 음성조절능력을 분석할 필요가 있다.

집단 내에서 인공와우이식 청년 집단의 개인적인 특성과 음성조 절능력 변수 간 상관관계를 분석한 결과, 단어 및 문장 자음정확도 와 VRP 기울기 간 높은 부적상관관계가 나타났다. 인공와우 이식 연령과 착용기간은 음성조절에 큰 영향을 미친다는 선행연구(Cerrçi et al., 2006; Hocevar-Boltezar et al., 2005; Yoon et al., 2013)와 는 달리, 본 연구에서는 음성조절능력과의 연관성은 나타나지 않 았다. 이처럼 상이한 결과는 연구 대상자의 특성에서 비롯되는 것 으로 사료된다. 본 연구에 참여한 인공와우이식 청년은 모두 만 7세 이전에 수술하여 10 년 이상 인공와우를 착용하였고, 단음절 말지 각 점수가 평균 90.77\%로 양호했으며, 선천성 농인은 최소 4년 이 상, 후천성 농인은 최소 2 년 이상 언어재활을 받은 경험이 있었다.
또한, 모든 대상자가 일반학급에 진학하여 정상 청력 청년과 사회 적 관계망을 형성하며 음성적 피드백을 통해 자신의 음성을 조절 하는 능력을 발달시켰다. 일측-양측 인공와우이식 청년 간 음성조 절능력의 차이는 없었지만, 본 연구에서는 일측 인공와우이식 청년 (6명)과 양측 인공와우이식 청년(6명)이 연구에 참여하여 인공와 우 착용 귀가 통제되지 않았다는 제한점이 있다. 이와 같은 이유들 과 함께 본 연구 대상자의 수가 작아 인공와우이식 연령 또는 착용 기간과 음성조절능력 간 유의한 상관관계를 밝혀내기 어려웠던 것 으로 사료된다. 그럼에도 단어 및 문장 자음정확도와 VRP 기울기 간에는 강한 부적상관관계가 있는 것으로 나타났다. 즉, 자음정확 도가 높을수록 VRP 기울기가 완만하게 나타나 자음정확도가 인 공와우이식 청년의 음성조절능력을 예측하는 강력한 변인으로 추 론할 수 있다. 자음정확도는 말 명료도와 높은 상관이 있는 것으로 보고되었으며(Heo \& Ha, 2010; Lee et al., 2011), 본 연구의 결과는 일상생활에서 인공와우이식 청년의 말 명료도와 음성조절 간 밀접 한 관계를 시사한다. 발화는 말 운동 조절(speech motor control)에 의해 이루어지는데, 말 운동 조절 기제는 정확한 조음과 음성조절 에 필수적이다(Kent, 2004; Kwon \& Son, 2010; Miller, Watkin, \& Chen, 2002). 따라서 자음정확도와 음성조절능력 변수인 VRP 기 울기 간 유의한 부적상관관계가 나타난 것으로 추론할 수 있다. 다 만, 본 연구에서 VRP는 실제 발화자료가 아닌 모음 /a/ 발성을 통해 음성조절능력을 분석하였으므로 실제 인공와우이식 청년의 구어 의사소통 능력과 연결시키는 것에 한계가 있을 것으로 사료된다.

본 연구는 인공와우이식 청년의 음성적 특성이 발달과정을 지나 며 정상 청력 청년과 유사해진다는 선행연구 결과(Hamzavi et al., 2000; Yoon et al., 2013)를 기반으로 하여 음도와 강도를 포함한 음 성조절의 역동성을 보고자 한 점에 의의가 있다. 음도와 강도 각각 의 측정치에 대해서는 집단 간 유의한 차이가 나타나지 않았으나, 음성역동면적에 대해서는 집단 간 유의한 차이가 나타났으며, 시각 적 피드백 유무에 따른 집단 간 차이도 유의한 것으로 나타났다. 따 라서 음성역동면적은 인공와우이식 청년의 음성조절능력을 민감 하게 측정하는 변수로서 적절할 것으로 사료된다. 추가적으로, 인 공와우이식 청년 집단 내에서 나뉜 선천성과 후천성 집단의 음성 조절능력에 대한 질적분석 결과, 두 집단 간 음성역동면적과 VRP 기울기의 차이가 유의하지 않은 것으로 나타났다. 두 집단은 언어 청능재활을 받은 기간의 차이가 분명했지만, 대상자 수가 작아 음 성조절능력의 차이가 유의하지 않았던 것으로 사료된다. 그러나 본 연구결과를 통하여 인공와우이식 청년의 음성을 조절하는 능력은 발달과정 동안 정상적인 청각적 피드백이 지속적으로 제공되어야 하는 것과 역동적인 음성조절능력 발달을 위한 재활 프로그램의 
필요성이 강조될 수 있다. 정상적인 듣기경험이 후두발달 완성기까 지 지속되지 못하면 성문하압을 형성하는 폐 주변 근육과 성대를 조절하는 후두 주변 신경근육의 협응이 더 발달하지 못하고 정체 될 수 있다는 점을 고려할 때, 시-청각적 피드백과 함께 다양한 자 료를 통해 음성조절능력을 향상시킬 수 있는 재활 프로그램의 개 발이 요구된다. 임상현장에서는 인공와우이식 아동 및 청년을 평 가하고 치료함에 있어서 음성 문제를 간과해서는 안 되며, 인공와 우이식 후 호흡, 발성, 공명, 조음 메커니즘의 원활한 협응과 음성조 절을 목표로 한 언어청능재활이 이루어져야 할 것이다.

본 연구의 제한점은 다음과 같다. 첫째, 본 연구에 참여한 집단별 대상자 수는 본 연구의 결과 및 집단을 대표하기에 적은 수이기 때 문에, 인공와우이식 청년의 음성조절능력을 대표할 수 없어 해석 에 주의가 필요하다. 둘째, 본 연구에서 사용한 도구인 CSL은 고가 의 장비로 모든 임상현장에서 사용하는 데 제약이 따르기 때문에, 음성조절능력을 평가할 수 있는 간편한 도구의 개발이 요구된다. 셋째, 본 연구에서 자음정확도와 VRP 기울기 간 강한 부적상관관 계가 있는 것으로 나타나 자음정확도가 인공와우이식 청년의 음성 조절능력을 예측하는 변인으로 추론할 수 있었다. 이는 인공와우 이식 청년의 말 명료도와 음성조절 간 밀접한 관계를 시사하지만, 본 연구에서는 실제 발화가 아닌 모음/a/ 발성을 기초로 한 음성조 절능력을 음향학적으로 분석한 것이므로 실제 인공와우이식 청년 의 구어의사소통 능력과 연결시키는 것에는 한계가 있을 것으로 사 료된다. 이에 음향학적 분석과 함께 공기역학적, 청지각적 분석을 포괄한 화자의 전반적인 음성조절능력을 알아볼 필요가 있으며, 실제 발화 자료를 이용한 후속연구가 요구된다. 마지막으로, 인공 와우이식 청년은 청각적 피드백의 제한으로 자신의 음성을 세밀하 게 조절하기 매우 어렵다. 따라서 시각적 피드백을 통한 음성조절 재활훈련을 할 때, 언어재활사는 인공와우이식 청년에게 정확한 수 행방법과 모델링을 반드시 제공하여야 할 것이다.

\section{REFERENCES}

Airainer, R., \& Klingholz, F. (1991). Computer-assisted phonetography as a diagnostic aid in functional dysphonia. Laryngorhinootologie, 70(7), 362366.

Åkerlund, L., \& Gramming, P. (1994). Average loudness level, mean fundamental frequency, and subglottal pressure: comparison between female singers and nonsingers. Journal of Voice, 8(3), 263-270.

American Speech-Language-Hearing Association. (2020). Hearing loss at birth (congenital hearing loss). Retrieved from www.asha.org.
Archbold, S. M., Harris, M., O’Donoghue, G., Nikolopoulos, T., White, A., \& Richmond, H. L. (2008). Reading abilities after cochlear implantation: the effect of age at implantation on outcomes at 5 and 7 years after implantation. International Journal of Pediatric Otorhinolaryngology, 72(10), 14711478.

Arend, M. S., Harm, K. S., \& Donald, G. M. (1995). Differences in phonetogram features between male and female subjects with and without vocal training. Journal of Voice, 9(4), 363-377.

Awan, S. N. (1993). Superimposition of speaking voice characteristics and phonetograms in untrained and trained vocal groups. Journal of Voice, 7(1), 30-37.

Bae, I. H. (2011). A study on change of voice range profile according to cochlear implantation (Master's thesis). Daegu University, Gyeongbuk, Korea.

Bae, I. H., Park, H. J., Kwon, S. B., Lee, I. W., \& Koh, E. K. (2014). The change of vocal performance according to cochlear implantation: for 1 year. Journal of Speech Language \& Hearing Disorders, 23(1), 253-272.

Boone, D. R. (1966). Modification of the voice of deaf children. Volta Review, 68, 686-692.

Boone, D. R., McFarlane, S. C., Von Berg, S. L., \& Zraick, R. I. (2014). Voice and voice therapy. USA: Pearson.

Buekers, R. (1995). Pitch adjustment in speaking levels. Proceedings of the 23rd World Congress IALP, 9-13.

Caffier, P. P., Müller, C., Freymann, M. L., Nawka, T., Möller, A., \& Forbes, E. (2018). The vocal extent measure: development of a novel parameter in voice diagnostics and initial clinical experience. BioMed Research International, 2018, 1-10.

Campisi, P., Low, A., Papsin, B., Mount, R., Cohen, R., \& Harison, R. (2005). Acoustic analysis of the voice in pediatric cochlear implant recipients: a longitudinal study. Laryngoscope, 115(6), 1046-1050.

Cerçi, U., Kandoğan, T., Olgun, L., Gültekin, G., Alper, S. (2006). The effect of cochlear implantation on voice development. Journal of Ear, Nose, and Throat, 16(3), 112-21.

Chen, S. H. (2007). Sex differences in frequency and intensity in reading and voice range profiles for Taiwanese adult speakers. Folia Phoniatrica et Logopaedica, 59, 1-9.

Choi, E., Park, H., \& Seong, C. (2009). The phonatory characteristics of the profound hearing-impaired adults' voice: with reference to F0, intensity, and their perturbations. Phonetics and Speech Sciences, 1(4), 177-185.

Choi, E., \& Park, H. (2010). Phonation characteristics in the voices of adults with profound hearing-impairment: reference to $\mathrm{H} 1-\mathrm{H} 2$ and spectral tilt 
of the source spectrum. Korean Journal of Communication \& Disorders, 15(4), 494-505.

Choi, S. H. (2013). Speech-language pathologists' voice assessment and voice therapy practices: a survey for standard clinical guideline and evidencebased practice. Communication Sciences \& Disorders, 18(4), 473-485.

Elizabeth, A., Justin, M. A., Abbigail, K., EmilyAnn, O., \& Bailey, H. (2018). Cochlear implant users' vocal control correlates across tasks. Journal of Voice, 34(3), 490.e7-490.e10.

Estella, M., Jennie, R., Claire, R., Sarah, V., Ruba, E. H., \& Edwin, Y. (2007). Reliability of speaking and maximum voice range measures in screening for dysphonia. Journal of Voice, 21(4), 397-406.

Euh, S. J., \& Yoon, M. S. (2005). The effect of visual feedback intervention on voice pitch of adult with hearing impairment. The Korean Journal of Speech Sciences, 12(4), 215-226.

Ferrand, C. T. (2012). Voice disorders: Scope of theory and practice. Boston, MA: Pearson Education Inc.

Gfeller, K., Driscoll, V., Kenworthy, M., \& Van, T. V. (2011). Music therapy for preschool cochlear implant recipients. Music Therapy Perspectives, 29(1), 39-49.

Gilbert, H. R., \& Campbell, M. I. (1980). Speaking fundamental frequency in three groups of hearing impaired individuals. Journal of Communication Disorders, 13(3), 195-205.

Gramming, P., Sundberg, J., Ternstrom, S., Leandersson, R., \& Perkins, W. (1988). Relationship between changes in voice pitch and loudness. Journal of Voice, 2(2), 118-126.

Hamzavi, J., Deutsch, W., Baumgartner, W. D., Bigenzahn, W., \& Gstoettner, W. (2000). Short-term effect of auditory feedback on fundamental frequency after cochlear implantation. Audiology, 39(2). 102-105.

Heo, H. S., \& Ha, S. (2010). The relationship between speech intelligibility and comprehensibility for children with cochlear implants. Phonetics and Speech Sciences, 2(3), 171-178.

Hocevar-Boltezar, I., Radsel, Z., Vatovec, J., Geczy, B., Cernelc, S., Gros, A., Zupancic, J., Battelino, S., Lavrencak, B., \& Zargi, M. (2006). Change of phonation control after cochlear implantation. Otology \& Neurotology, 27(4), 499-503.

Huh, M. J., \& Jeong, O. R. (1997). Acoustic characteristics of prelingual hearing impaired speakers. Journal of Speech \& Hearing Disorders, 6(1), 61-77.

Jung, M. (2010). The effect of music perception program training on music perception of wear cochlear implant (Master's thesis). Kosin University, Yeongdo, Busan.
Jung, W. J., Choi, S. H., \& Choi, C. H. (2019). Development and validation of a novel simplified voice range profile measurement method: comparison of maximum vocal performance based on the VRP protocol. Communication Sciences \& Disorders, 24(3), 770-784.

Kang, Y. (2006). A normative study of the Korean-mini mental state examination (K-MMSE) in the elderly. Korean Journal of Psychology: General, 25(2), 1-12.

Kent, R. D. (2004). The uniqueness of speech among motor systems. Clinical Linguistics \& Phonetics, 18(6-8), 495-505.

Kim, C. (2003). Digital image processing using MATLAB. Hongreung publishing company.

Kim, D. H., \& Yoon, M. S. (2017). Predicting the quality of communication life of university students with hearing loss. Communication Sciences \& Disorders, 22(4), 827-836.

Kim, H. (2016). Case studies on sequential interval imitation singing for pitch production improvement in children with cochlear implants (Master's thesis). Ewha Womans University, Seoul, Korea.

Kim, G., \& Ko, D. H. (2007). Acoustic characteristics of some vowels produced by the CI children of various age groups. The Korean Journal of Speech Sciences, 14(4), 203-212.

Kim, S. (2008). Fundamental frequencies of Korean according to age and gender (Doctoral dissertation). Hallym University, Chuncheon, Korea.

Kim, Y. T., Shin, M. J., Kim, S. J., \& Ha, J. W. (2020). Urimal test of articulation and phonology 2 (UTAP 2). Seoul: Hakjisa.

Ko, H. J., Kang, M. J., Kwon, H. J., Choi, Y., Lee, M. G., \& Choi, H. S. (2013). Acoustic characteristics on the adolescent period aged from 16 to 18 years. Phonetics and Speech Sciences, 5(1), 81-90.

Ko, J. (2008). A study on the measurement for vortex trajectory over an UCAV using image processing methods. Journal of the Korean Society for Aeronautical \& Space Sciences, 36(6), 594-599.

Kong, Y. Y., Mullangi, A., Marozeau, J., \& Epstein, M. (2011). Temporal and spectral cues for musical timbre perception in electric hearing. Journal of Speech, Language, and Hearing Research, 54(3), 981-994.

Kuk, M. K. (1994). The effects of pronunciation training using visual aids on the vowels and consonants stabilization in hearing impaired infants (Doctoral dissertation). Daegu University, Geongbuk, Korea.

Kwon, T. K., \& Son, H. Y. (2010). Movement disorders affecting the larynx. The Korean Society of Logopedics and Phoniatrics, 21(1), 22-26.

Langeries, M. C., Bosman, A., \& van Olphen, A. (1998). Effect of cochlear implantation on voice fundamental frequency in post-lingually deafened 
adults. Audiology, 37(4), 219-230.

Leder, S. B., Spitzer, J. B., \& Kirchner, J. C. (1987). Immediate effects of cochlear implantation on voice quality. Archives of Otorhinolaryngology, 244(2), 93-95.

Lee, G. S. (2012). Variability in voice fundamental frequency of sustained vowels in speakers with sensorineural hearing loss. Journal of Voice, 26(1), 24-29.

Lee, M. Y., Shin, J. C., Kim, H. H., \& Kim, L. S. (2009). Open-set monosyllabic speech perception test for preschool children. Korean Journal of Otorhinolaryngology-Head and Neck Surgery, 52(4), 312-321.

Lee, Y. M., Sung, J. E., Park, J. M., \& Sim, H. S. (2011). Effects of listeners experience, severity of speakers articulation, and linguistic cues on speech intelligibility in congenitally deafened adults with cochlear implants. Phonetics and Speech Science, 3(1), 125-134.

Louis, H., Floris, L. W., Fons, M., Marc, D. B., Jos, P., Chirstophe, C., \& Paul, H. (1998). Evaluation of the vocal performance of children using a voice range profile index. Journal of Speech, Language, and Hearing Research, 41(2), 232-238.

Maassen, B., \& Povel, D. J. (1985). The effect of segmental and suprasegmental corrections on the intelligibility of deaf speech. The Journal of the Acoustical Society of America, 78(3), 877-886.

Manrique, M., Cervera-Paz, F. J., Huarte, A., Perez, N., Molina, M., \& GarciaTapia, R. (1999). Cerebral auditory plasticity and cochlear implants. International Journal of Pediatric Otorhinolaryngology, 49(1), 193-197.

Miller, J. L., Watkin, K. L., \& Chen, M. F. (2002). Muscle, adipose, and connective tissue variations in intrinsic musculature of the adult human tongue. Journal of Speech, Language, and Hearing Research, 45(1), 51-65.

Nadine, L. A., Mike, B., Sophi, K. S., \& Carolyn, M. (2019). Flexible voices: identity perception from variable vocal signals. Psychonomic Bulletin \& Review, 26(1), 90-102.

Nora, S., \& Hugo, L. (2010). Effects of vocal training on singing and speaking voice characteristics in vocally healthy adults and children based on choral and nonchoral data. Journal of Voice, 25(4), 177-189.

O’Donoghue, G. M., Nikolopoulos, T. P., Archbold, S. M., \& Tait, M. (1998). Speech perception in children after cochlear implantation. American Journal of Otology, 19(6), 762-767.

Pabon, P. (1991). Objective acoustic voice-quality parameters in the computer phonetogram. Journal of Voice, 5(3), 203-216.

Pedersen, M. F. (1993). A longitudinal pilot study on phonetograms/voice profiles in pre-pubertal choir boys. Clin Otolaryngol Allied Sci, 18(6), 488-
491.

Pyo, H. (2007). The study on the speech intelligibility of patients with voice disorders according to the level of degradation of voice quality (Doctoral dissertation). Ewha Womans University, Seoul, Korea.

Pratt, S. R., Heintzelman, A., \& Deming, S. (1993). The efficacy of using the IBM Speech Viewer vowel accuracy module to treat young children with hearing impairment. Journal of Speech \& Hearing Research, 36(5), 63-74.

Ryalls, J., Michallet, B., \& Le Dorze, G. (1994). A preliminary evaluation of the clinical effectiveness of vowel training for hearing-impaired children on IBM's Speech Viewer. The Volta Review, 96, 19-30.

Sanchez, K., Oates, J., Dacakis, G., \& Holmberg, E. B. (2014). Speech and voice range profiles of adults with untrained normal voices: Methodological implications. Logopedics Phoniatrics Vocology, 39(2), 62-71.

Seo, J. (1998). The effect of visual-feedback pronunciation training on pronunciation establishment for hearing-impaired children (Master's thesis). Daegu University, Geongbuk, Korea.

Shannon, R. V., Zeng, F. G., Kamath, V., Wygonski, J., \& Ekelid, M. (1995). Speech recognition with primarily temporal cues. Science, 270(5234), 303304.

Shin, Y. J., Hong, K. H., Hong, Y. T., Oh, J. S., Yoon, Y. S., \& Lee, H. D. (2014). Aerodynamic analysis of voice in patients with thyroidectomy. Journal of Korea Thyroid Association, 7(1), 77-82.

Smith, Z. M., Delgutte, B., \& Oxenham, A. J. (2002). Chimaeric sounds reveal dichotomies in auditory perception. Nature, 416(6876), 87-90.

Snow, D. P., \& Ertmer, D. J. (2012). Children's development of intonation during the first year of cochlear implant experience. Clinical Linguistics \& Phonetics, 26(1), 51-70.

Spector, P. B., Subtelny, J. D., Whitehead, R. L., \& Wirz, S. L. (1979). Description and evaluation of a training program to reduce vocal tension in adult deaf speakers. The Volta Review, 81(2), 81-90.

Titze, I. R. (1994). Principles of voice production. United States of America, Prentice Hall.

Wang, S. G., Back, M. J., Kim, S. G., Moon, Y. I., Roh, H. J., Goh, E. K., \& Chon, K. M. (1996). The acoustic analysis of pubertal voice change. Korean Journal of Otorhinolaryngology-Head and Neck Surgery, 39(12), 2022-2032.

Wang, D. J., Trehub, S. E., Volkova, A., \& van Lieshout, P. (2013). Child implant users' imitation of happy-and sad-sounding speech. Frontiers in Psychology, 4, 1-8.

Yoon, M. H. (2018). A study on related factors of sentence speech production intelligibility in preschool children with cochlear implants (Master's thesis). 
Ewha Womans University, Seoul, Korea.

Yoon, M. S. (2003). The predicting variables of speech production abilities and speech characteristics in prelingually deafened children with cochlear implantation (Doctoral dissertation). Ewha Womans University, Seoul, Korea.

Yoon, M. S. (2006). Comparison of voice characteristics: among children with cochlear implant, children with hearing aids, and children with normal hearing. Proceedings of the conference of the Korean Speech-Language \& Hearing Association, 63-70.

Yoon, M., Choi, E., \& Sung, Y. (2013). A comparison of voice analysis of children with cochlear implant and with normal hearing. Phonetics and Speech Sciences, 5(4), 71-78.
Yoon, M., Lee, Y., \& Sim, H. S. (2001). The relationship between speech intelligibility and related factors of speakers in prelingually hearing impaired children using hearing aids. Korean Journal of Communication \& Disorders, 5(2), 1-15.

Yorkston, K. M., \& Beukelman, D. E. (1981). Ataxic dysarthria: treatment sequences based on intelligibility and prosodic considerations. Journal of Speech and Hearing Disorders, 46(4), 398-404.

Youdelman, K., MacEachron, M., \& McGarr, N. S. (1989). Using visual and tactile sensory aids to remediate monotone voices in hearing-impaired speakers. The Volta Review, 91(4), 197-208. 
Appendix 1. Auditory information of young adults with cochlear implants

\begin{tabular}{|c|c|c|c|c|c|c|c|c|c|c|c|}
\hline \multirow{3}{*}{ ID } & \multirow{3}{*}{ Sex } & \multirow{3}{*}{$\begin{array}{l}\text { Age } \\
(y r)\end{array}$} & \multirow{3}{*}{$\begin{array}{c}\text { Onset of } \\
\text { hearing loss }\end{array}$} & \multicolumn{2}{|c|}{ Age at implantation (yr) } & \multicolumn{2}{|c|}{ Duration of implant use (yr) } & \multicolumn{4}{|c|}{ Hearing threshold (dB) } \\
\hline & & & & \multirow{2}{*}{ Lt. } & \multirow{2}{*}{ Rt. } & \multirow{2}{*}{ Lt. } & \multirow{2}{*}{ Rt. } & \multicolumn{2}{|c|}{ Before } & \multicolumn{2}{|c|}{ After } \\
\hline & & & & & & & & Lt. & Rt. & Lt. & Rt. \\
\hline 1 & $M$ & 22 & Congenital deaf & - & 5 & - & 17 & 100 & 100 & - & 35 \\
\hline 2 & $\mathrm{~F}$ & 19 & & - & 3 & - & 16 & 100 & $100 \uparrow$ & - & $25-30$ \\
\hline 3 & $\mathrm{~F}$ & 19 & & 1 & 7 & 18 & 12 & $100 \uparrow$ & $100 \uparrow$ & 10 & $15-20$ \\
\hline 4 & $\mathrm{~F}$ & 25 & & 3 & 13 & 22 & 12 & $100 \uparrow$ & $100 \uparrow$ & 25 & 25 \\
\hline 5 & $\mathrm{~F}$ & 20 & & 2 & 6 & 18 & 13 & 100 & 100 & 20 & 20 \\
\hline 6 & $\mathrm{~F}$ & 18 & & - & 4 & - & 14 & 70 & 120 & - & $20-25$ \\
\hline 7 & $\mathrm{~F}$ & 20 & & - & 2 & - & 18 & 120 & 120 & - & 30 \\
\hline 8 & $\mathrm{M}$ & 21 & Acquired deaf & 9 & 4 & 12 & 17 & 70 & 80 & 25 & 25 \\
\hline 9 & $M$ & 20 & & 4 & 11 & 16 & 9 & 120 & 120 & 31.6 & 30 \\
\hline 10 & $\mathrm{~F}$ & 20 & & 6 & - & 14 & - & 90 & 90 & 40 & - \\
\hline 11 & $\mathrm{M}$ & 16 & & - & 3 & - & 13 & 100 & 114 & - & 10 \\
\hline 12 & $\mathrm{~F}$ & 20 & & - & 4 & - & 16 & 97.5 & 114 & - & 25 \\
\hline
\end{tabular}

$\mathrm{M}=$ Male; $\mathrm{F}=$ Female. 
Appendix 2. Example of visual feedback using voice tools

1) Example of decreasing frequencies

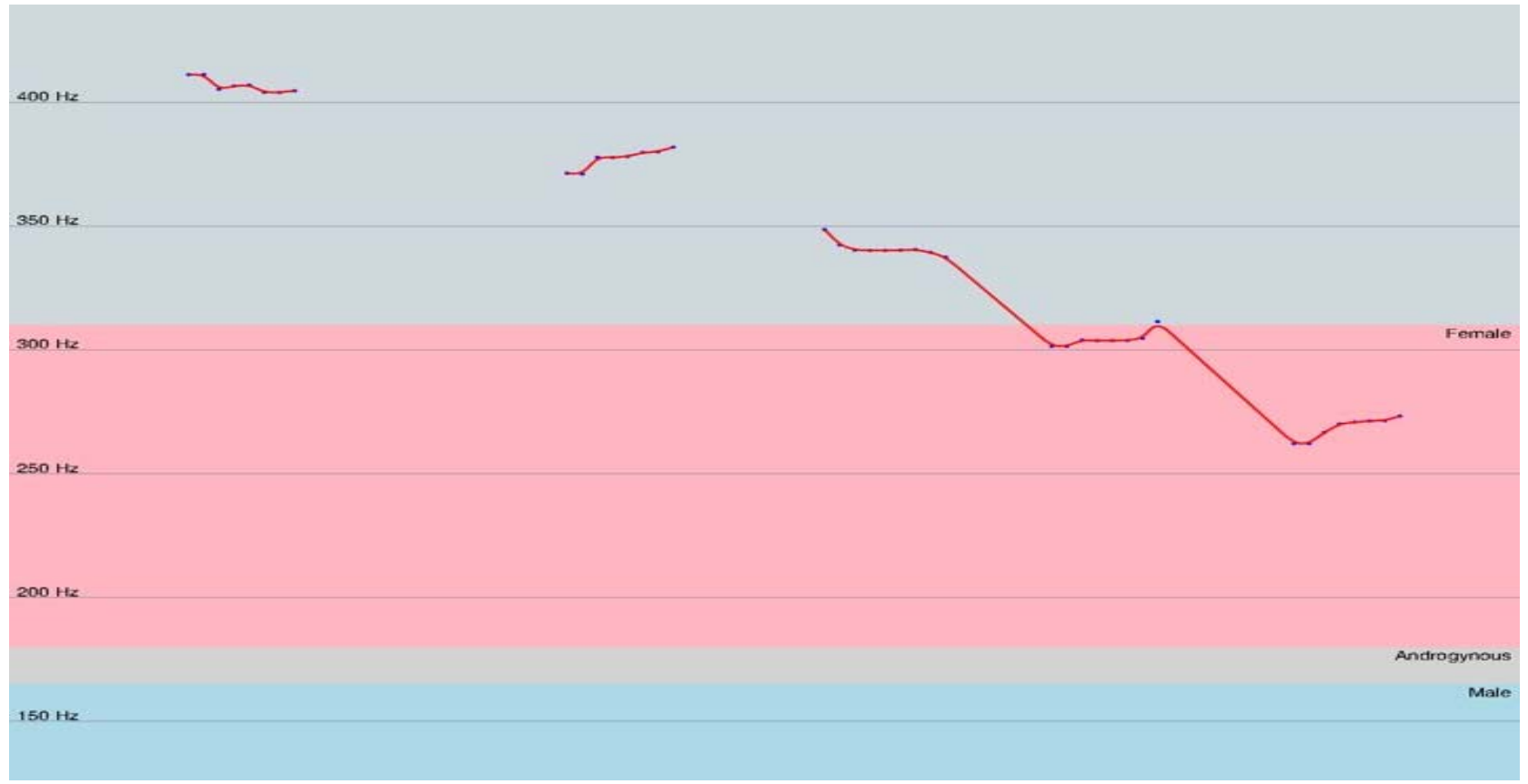

2) Example of decreasing intensities

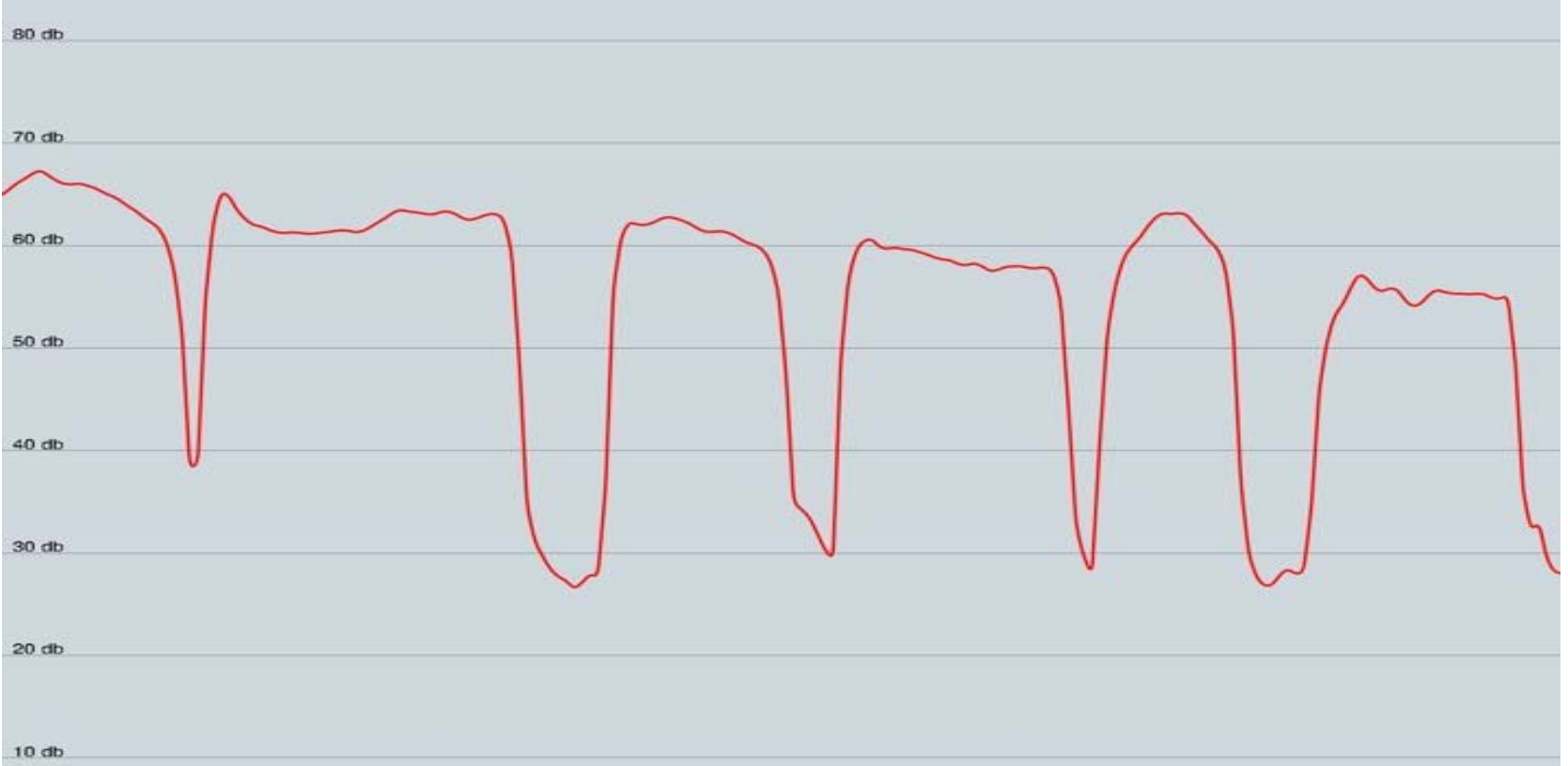




\title{
국문초록
}

\author{
시각적 피드백 유무에 따른 인공와우이식 청년의 음성조절능력 \\ 강지은 · 이영미 · 심현섭 \\ 이화여자대학교 대학원 언어병리학과
}

배경 및 목적: 본 연구는 인공와우이식 청년과 정상 청력 청년 간 음성조절능력에 차이가 있는지 알아보고자 하였다. 또한 인공와우이 식 청년의 인공와우 관련정보, 수행력과 음성조절능력 변수(음성역동면적, VRP 기울기) 간 상관관계를 알아보고자 하였다. 방법: 본 연구에서는 만 7 세 이전에 인공와우를 이식한 청년 12 명(여성 8 명, 남성 4 명)과 성별 및 연령을 일치시킨 정상 청력 청년 12 명이 참여하 였다. 시각적 피드백 유무에 따른 음성조절능력을 평가하기 위해 음성범위프로파일(VRP)이 사용되었다. 결과: 정상 청력 청년의 음성 역동면적은 인공와우이식 청년보다 유의하게 컸으며, 청각에만 의존하는 것보다 시-청각적 피드백이 제공되었을 때 음성역동면적이 유 의하게 컸다. VRP 기울기는 두 집단 간 차이가 통계적으로 유의하지 않았지만, 청각적 피드백만 제시되었을 때보다 시-청각적 피드백 제공시의 기울기가 유의하게 작았다. 인공와우이식 청년 집단의 자음정확도와 VRP 기울기 간에는 강한 부적상관관계가 나타났다. 논 의 및 결론: 만 7세 이전에 인공와우를 이식한 선천성 농인은 생활연령이 일치하는 정상 청력 청년과 같이 정상적인 음성조절능력을 보 이지 않았다. 그러나 인공와우이식 청년은 음성조절을 위해 시각적 정보를 활용할 수 있었다. 음성역동면적은 음성조절능력을 측정하 는 변수로서 적절하나, 음성역동면적과 VRP 기울기는 상호보완적인 관계로 결과를 분석할 때 함께 고려하여야한다.

핵심어: 음성조절, 음성범위프로파일, 음성역동면적, VRP 기울기, 인공와우이식, 시각적 피드백

\section{참고문헌}

강연욱 (2006). K-MMSE (Korean-mini mental state examination)의 노인 규준 연구. 한국심리학회지: 일반, 25(2), 1-12.

고지훈 (2008). 영상처리기법을 이용한 무인전투기 와류 궤적 계측에 관한 연구. 한국항공우주학회지, 36(6), 594-599.

고혜주, 강민재, 권혁제, 최예린, 이미금, 최홍식 (2013). 16-18세 청소년기 음성의 음향음성학적 특성. 말소리와음성과학, 5(1), 81-90.

국미경 (1994). 시각적 기기를 이용한 발음훈련이 청각장애유아의 자모음 발음안정에 미치는 효과. 대구대학교 대학원 박사학위논문.

권택균, 손희영 (2010). 후두운동장애. 대한음성언어의학회지, 21(1),22-26.

김고은, 고도흥 (2007). 인공와우 이식 시기에 따른 모음의 음향음성학적 특성. 음성과학, 14(4), 203-212.

김선해 (2008). 연령별 성별에 따른 한국인의 기본 주파수 연구. 한림대학교 대학원 박사학위논문.

김다혜, 윤미선 (2017). 청각장애 대학생의 의사소통 삶의 질 예측변인. Communication Sciences \& Disorders, 22(4), 827-836.

김영태, 신문자, 김수진, 하지완 (2020). 우리말조음음운검사 2 (Urimal Test of Articulation and Phonology 2, UTAP 2). 서울: 학지사.

김충원 (2003). MATLAB을 이용한 디지털 영상처리. 홍릉과학출판사.

김효진 (2016). 음정모방 중심 노래부르기를 통한 인공와우 이식 아동의 음고산출 향상 사례. 이화여자대학교 대학원 석사학위논문.

배인호, 박희준, 권순복, 이일우, 고의경 (2014). 인공와우 이식에 따른 발성수행력 변화에 관한 연구 . 언어치료연구, 23(1), 253-272.

배인호 (2011). 인공와우 이식에 따른 Voice Range Profile 변화에 관한 연구. 대구대학교 대학원 석사학위논문.

서정원 (1998). 시각적 피드백 발음훈련이 청각장애 아동의 발음확립에 미치는 효과. 대구대학교 대학원 석사학위논문.

신유정, 홍기환, 홍용태, 오정석, 윤연섭, 이현두 (2005). 갑상선절제술 환자 음성의 공기역학적 분석. 대한갑상선학회지, 7(1), $77-82$.

어수지, 윤미선 (2005). 선천성 청각장애성인의 시각적피드백 이용 음도치료 효과. 음성과학, 12(4), 215-226.

윤매화 (2018). 학령전 인공와우이식 아동의 문장 말명료도 능력에 대한 관련요인 연구. 이화여자대학교 대학원 석사학위논문.

윤미선 (2003). 선천성 심도청각장애 아동의 와우이식 후 말산출 능력의 예측변인 및 말산출특성. 이화여자대학교 대학원 박사학위논문.

윤미선 (2006). 청각적 피드백의 차이에 따른 음성 특성 비교: 인공와우이식 아동, 보청기 사용 아동, 건청 아동에서. 한국언어치료학회 학술발표대회 


\section{논문집, 63-70.}

윤미선, 이윤경, 심현섭 (2001). 청각장애아동의 말명료도에 영향을 미치는 화자 요인. 언어청각장애연구, 5(2), 1-15.

윤미선, 최은아, 성영주 (2013). 인공와우이식 아동과 건청 아동의 음성 분석 비교. 말소리와 음성과학, 5(4), 71-78.

왕수건, 백무진, 김서규, 문영일, 노환중, 고의경, 전경명 (1996). 변성기를 전후한 학동의 음성학적 고찰. 대한이비인후과학회지, 39(12), $2022-2032$.

이미영, 신지철, 김향희, 김리석 (2009). 학령 전 아동의 단음절 말지각 검사 개발. 대한이비인후과학회지 두경부외과학, 52(3), 312-321.

이영미, 성지은, 박정미, 심현섭 (2011). 청자의 경험, 화자의 조음 중증도, 단서 유형이 인공와우이식 선천성 농 성인의 말명료도에 미치는 영향. 말소리

와음성과학, 3(1), 125-134.

정미라 (2010). 음악지각 훈련프로그램이 인공와우 착용 아동의 음악지각에 미치는 효과. 고신대학교 대학원 석사학위 논문.

정원정, 최성희, 최철희 (2019). 새로운 축약된 음성범위프로파일 검사법 개발과 타당도. Communication Sciences \& Disorders, 24(3), 770-784.

최성희 (2013). 음성언어재활사의 음성평가와 음성치료의 임상실제: 표준 임상지침과 증거기반중재를 위한 설문조사. Communication Sciences \&

Disorders, 18(4), 473-485.

최은아, 박한상 (2010). 심도 청각장애 성인의 발성 특성. 언어청각장애연구, 15(4), 494-505.

최은아, 박한상, 성철재 (2009). 심도 청각장애 성인의 발성 특성: 강도, 음도, 및 그 변동율을 중심으로. 말소리와 음성과학, 1(4), 177-185.

표화영 (2007). 음질 저하의 정도에 따른 음성장애 환자 발화의 말 명료도 연구. 이화여자대학교 대학원 박사학위논문.

허명진, 정옥란 (1997). 언어습득 전 난청자의 음향학적 특성. 언어치료연구, 6(1), 61-77.

허현숙, 하승희 (2010). 조음중증도에 따른 인공와우이식 아동들의 말명료도와 이해가능도의 상관연구. 말소리와 음성과학, 2(3), 171-178.

\section{ORCID}

강지은(제1저자, 대학원생 https://orcid.org/0000-0002-9438-2147); 이영미(공동저자, 교수 https://orcid.org/0000-0003-1809-5944);

심현섭(교신저자, 교수 https://orcid.org/0000-0002-4710-3678) 